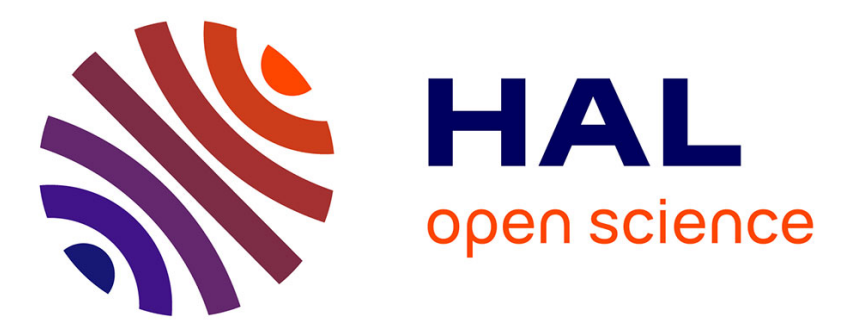

\title{
Multiple crust reworking in the French Armorican Variscan belt: implication for the genesis of uranium-fertile leucogranites
}

Christophe Ballouard, Marc Poujol, Armin Zeh

\section{To cite this version:}

Christophe Ballouard, Marc Poujol, Armin Zeh. Multiple crust reworking in the French Armorican Variscan belt: implication for the genesis of uranium-fertile leucogranites. International Journal of Earth Sciences, 2018, 107 (7), pp.2317-2336. 10.1007/s00531-018-1600-3 . insu-01717290

HAL Id: insu-01717290

https://hal-insu.archives-ouvertes.fr/insu-01717290

Submitted on 26 Feb 2018

HAL is a multi-disciplinary open access archive for the deposit and dissemination of scientific research documents, whether they are published or not. The documents may come from teaching and research institutions in France or abroad, or from public or private research centers.
L'archive ouverte pluridisciplinaire HAL, est destinée au dépôt et à la diffusion de documents scientifiques de niveau recherche, publiés ou non, émanant des établissements d'enseignement et de recherche français ou étrangers, des laboratoires publics ou privés. 


\section{Multiple crust reworking in the French Armorican Variscan belt:}

\section{implication for the genesis of uranium-fertile leucogranites}

1

\section{Ballouard ${ }^{\mathrm{a}, \mathrm{b} *}$, M. Poujol ${ }^{\mathrm{b}}$, A. Zeh ${ }^{\mathrm{c}}$}

aDepartment of Geology, University of Johannesburg, PO Box 254, Auckland Park 2006, South Africa

b Univ Rennes, CNRS, Géosciences Rennes - UMR 6118, F-35000 Rennes, France

${ }^{\mathrm{c}}$ Institute of Applied Geosciences - Karlsruhe Institute of Technology (KIT), Campus South, Mineralogy and Petrology, Adenauerring 20b, 50.4, D-76131 Karlsruhe, Germany

* Correspondence:

christopheballouard@ hotmail.fr, christopheb@uj.ac.za,+27648303568

Keywords: peraluminous granites, zircon $\mathrm{U}-\mathrm{Pb}$ dating, $\mathrm{Hf}-\mathrm{Nd}$ isotope analyses, Variscan orogeny, uranium metallogenesis

\section{Abstract}

Muscovite peraluminous granites (MPGs) form by partial melting of the continental crust and can be related to metalliferous deposits such as tin, tungsten and uranium (U). Metal enrichment in MPGs commonly results from fractional crystallization, but the metal contents of the source play a major role for their fertility. Between ca. 320 and 300 Ma (Late Carboniferous), the French Armorican Variscan belt was intruded by numerous U-fertile MPGs that contain inherited zircon grains with a wide range of ages from Archean-to-Carboniferous. U-Pb and $\mathrm{Hf}$ isotopic data of zircon grains from Brioverian-to-Carboniferous sediments, Cambrian-to-Early Carboniferous granitoids and Late Carboniferous MPGs indicate that the crust of the Armorican 
Massif is made up by detritus mainly derived from the West African craton (3500-1600 Ma; $\left.\mathrm{T}_{\mathrm{DM}}=3.8-2.3 \mathrm{Ga}\right)$, Grenvillian belt $\left(1200-900 \mathrm{Ma} ; \mathrm{T}_{\mathrm{DM}}=2.7-1.2 \mathrm{Ga}\right)$ and Avalonian-Cadomian belt $\left(800-550 \mathrm{Ma} ; \mathrm{T}_{\mathrm{DM}}=2.5-0.8 \mathrm{Ga}\right)$, and that the crust was affected by magmatic events at 510-470 Ma $\left(\mathrm{T}_{\mathrm{DM}}=1.6-0.6 \mathrm{Ga}\right), 410-330 \mathrm{Ma}\left(\mathrm{T}_{\mathrm{DM}}=1.6-1 \mathrm{Ga}\right)$ and 320-300 Ma. Furthermore, they reveal that the Late Carboniferous MPGs were mainly formed by partial melting of Brioverian sediments with Cambro-Ordovician and Devonian-Carboniferous granitoids, which are all genetically linked with each other and characterized by $\mathrm{Th} / \mathrm{U}<4$. The new data suggest that the U-fertile MPGs result from multiple reworking of U-rich Brioverian sediments, deposited ca. $550 \mathrm{Ma}$ ago on the northern margin of Gondwana, and partially molten during several Paleozoic events, causing a successive increase in U content in the middle-upper crust.

\section{Introduction}

In late orogenic setting, the partial melting of the crust during extensional and/or transcurrent tectonic regimes commonly lead to the emplacement of peraluminous granitoids (e.g. Barbarin 1999) including cordierite bearing peraluminous granites (CPGs), muscovite bearing peraluminous granites (MPGs; Barbarin 1996, 1999) and related LCT (lithium-cesiumtantalum) pegmatites (Černý and Ercit 2005). Peraluminous granites and pegmatites are generally considered to form by the partial melting of sedimentary rocks at lower or intermediate crustal levels (e.g. Bernard-Griffiths et al. 1985; Le Fort et al. 1987; Vielzeuf and Holloway 1988; Patiño-Douce and Johnston 1991; Montel and Vielzeuf 1997; Patiño-Douce 1999; Shaw et al. 2016) but highly peraluminous melts can also be produced through the partial melting of mica rich igneous rocks (e.g. Turpin et al. 1990; Castro et al. 1999; Villaseca et al. 2012; García-Arias et al. 2015; Gao et al. 2016; Laurent et al. 2017; López-Moro et al. 2017). MPGs and related pegmatites can be associated with various metalliferous deposits such as tin (Sn), tungsten (W), uranium (U), lithium ( $\mathrm{Li}$ ) and tantalum (Ta). The genesis of these deposits relates significantly to fractional crystallization and hydrothermalism but the pre-concentration 
of these lithophile elements in the source region submitted to partial melting is a necessary requirement for the genesis of peraluminous granites and pegmatites associated with economically significant metal deposits.

Recent studies (Romer and Kroner 2015, 2016) suggested that the formation of granites associated with Sn-W deposits and LCT pegmatites may result from weathering-related rare element enrichment in sediments prior to partial melting. Epicontinental black shales deposited after major glaciation events also have the capacity to trap a large amount of U (Cuney 2010) and their partial melting can lead to the formation of $U$ rich melts. Emplacement of igneous rocks formed by the partial melting of an enriched lithospheric mantle can also result in the enrichment of incompatible element in the continental crust (Cuney 2010). Furthermore, crustal reworking can achieve significant metal enrichment at the scale of the lower, middle and upper crust. During granulite-facies metamorphism, dehydration of the lower crust can lead to the production of fluids enriched in F, large ion lithophile elements and rare metals. These fluids, preferentially channeled along regional shear zones, may enhance the partial melting of the middle crust resulting in the formation of magmas enriched in rare metals and $U$ (Cuney and Barbey 2014). A comparable model was proposed by Eglinger et al. (2016) in the Pan African Lufilian belt where a crustal-scale Ca-Na metasomatism has leached $\mathrm{U}$ from the basement, and transported and redistribute it into supracrustal rocks along the brittle-ductile transition. Finally, crustal-derived magmatism can also induce significant metal mobility at the scale of the crust. Such process is well recorded in the uraniferous Mesoproterozoic western Namaqua province (South Africa) where voluminous granitic magmatism, recorded for a period of about $200 \mathrm{Ma}$, led to progressive U enrichment of the lower-middle crust (e.g. Andreoli et al. 2006).

In the European Variscan belt (EVB), a large proportion of the hydrothermal U deposits are spatially associated with uraninite bearing low-Ca Late Carboniferous MPGs (e.g. Cathelineau et al. 1990; Cuney et al. 1990; Tischendorf and Förster 1994; Ballouard et al. 2017a, in press) 
(Fig. 1) and in the Armorican Massif (French part of the EVB) $20.000 \mathrm{t}$ of U (20\% of the French production; UDEPO database: https://infcis.iaea.org) were extracted from the deposits spatially associated with the syntectonic MPGs (leucogranites) emplaced in the southern part of the massif (Fig. 2). Overall, most of the MPGs emplaced along the south Armorican shear zone (SASZ), a lithospheric scale strike-slip fault (e.g. Jégouzo 1980; Gumiaux et al. 2004a, b; Gapais et al. 2015), appear to be U-fertile, either because they are the source for several economically significant U deposits, such as the Mortagne (Cathelineau 1982) and Pontivy (Marcoux 1982; Ballouard et al., in press) MPGs or because they liberated an important amount of U during post-magmatic hydrothermal alteration, such as the Questembert MPG (Tartèse et al. 2013). In contrast, MPGs that were emplaced in extensional setting to the south of the SASZ (Gapais et al. 2015), are barren. The only exception is the U-fertile Guérande MPG, which is spatially associated with U deposits (Cathelineau 1981; Ballouard et al. 2017a). The distribution of the U-rich MPGs in the Armorican Massif fits widely the distribution of the so-called high heat production and flow belt (HHPFB; Fig. 2) defined by Jolivet et al. (1989) and Vigneresse et al. (1989). This belt shows a NW-SE orientation, is ca. $50 \mathrm{~km}$ wide, and characterized by an elevated heat flux. Granites in this belt have heat production values more than twice the values of the surrounding geological formations (Jolivet et al. 1989; Vigneresse et al. 1989). Vigneresse et al. (1989) therefore suggested that the HHPFB reflects the presence of an upper to intermediate continental crust enriched in radioactive elements and that partial melting of this crust caused the formation of U-fertile MPGs.

Recent studies focused mainly on the detailed deciphering of intramagmatic and hydrothermal processes leading to the genesis of the $U$ deposits associated with the Guérande and Pontivy MPGs (Ballouard et al. 2015a, 2017a, 2017b, in press). However, the more global reasons behind the U-fertility of the MPGs in the Armorican Massif, and particularly the role of their source(s), remain unclear. To place new constraints on this open issue new sets of data 
are presented in this study, comprising whole rock trace elements and $\mathrm{Nd}-\mathrm{Sr}$ isotopic analyses, $\mathrm{U}-\mathrm{Pb}$ ages and $\mathrm{Hf}$ isotopic data of inherited zircon grains from Late Carboniferous MPGs, detrital zircon from Brioverian to Carboniferous sedimentary rocks and zircon crystals from pre-Late Carboniferous igneous rocks surrounding the MPGs. Finally, the implication of the new data sets for the genesis of U-fertile MPGs is discussed.

\section{Geological context}

The Armorican Massif belongs to the European Variscan Belt (EVB), a Paleozoic orogenic belt that extends from Western (Iberian Massif) to Central Europe (Bohemian Massif) and results from the convergence of the Gondwana and Avalonia continents (Fig. 1;) (Ballèvre et al. 2009, 2013, 2014; Kroner and Romer 2013). The oldest rocks from the European Variscan belts are the Icartian orthogneisses that outcrop sporadically to the north of the Armorican Massif (Vidal et al. 1981). These, ca. 2 Ga old metagranitoids, are the witnesses of a Paleoproterozoic continental crust (Samson and D'lemos 1998). The Neoproterozoic-Cambrian Cadomian orogeny represents the main Pre-Variscan orogenic event (Linnemann et al. 2008, 2014). Strong Cadomian imprints are preserved in the Saxo-Thuringian domains of the Bohemian and Iberian Massifs, and the main type locality is the northern part of the Armorican Massif (Figs. 1 and 2). The Cadomian-Avalonian orogen is the result of the succession of variable geodynamic events occurring along the northern margin of the West African craton (Gondwana). These events include the formation of a continental magmatic arc from ca. 750 to $570 \mathrm{Ma}$, back-arc basin closure followed by arc-continent collision from ca. 570 to $540 \mathrm{Ma}$ and major granitoid magmatism at ca. $540 \mathrm{Ma}$ (Linnemann et al. 2008, 2014, Koglin et al. 2018). During the Cambro-Ordovician (ca. 510 - $470 \mathrm{Ma}$ ), a widespread extension event, leading to the separation of continental micro-blocks (Ibero-Armorica) from the northern Gondwana margin, induced an important magmatism related to the emplacement of various granitoids and volcanic rocks (Fig. 1) (Ballèvre et al. 2012, 2013, 2014; Kroner and Romer 2013; Villaseca et 
al. 2016; Koglin et al. 2018). Subduction of oceanic then continental domains in the EVB occurred until ca. 350-340 Ma and transition from a compressive to an extensive regime occurred at ca. 315-310 Ma (Kroner and Romer 2013; Ballèvre et al. 2014). From Middle Carboniferous to Early Permian (e.g. Romer et al. 2007; Martínez Catalán et al. 2014; Laurent et al. 2017; Ballouard et al. 2017b), the EVB experienced an important magmatism leading to emplacement of crustal-derived MPGs and CPGs as well as hybrid or mantle-derived K-rich K-feldspar porphyritic calc-alkaline (KCGs) and amphibole-rich calc-alkaline (ACGs) granitoids (Barbarin 1999) (Fig. 1). The EVB represents an important metallogenic province for $U$ where vein, episyenite-type, breccia-hosted or shear zone-hosted $U$ deposits occur throughout the belt (Fig. 1). A large proportion of these hydrothermal deposits are spatially associated with Late Carboniferous MPGs and mineralizing events mostly occurred during the Permian from ca. 300 to 260 Ma (e.g. Cathelineau et al. 1990; Cuney et al. 1990; Tischendorf and Förster 1994; Cuney and Kyser 2008; Romer et al. 2010; Ballouard et al. 2017a, in press).

The Armorican Massif is separated into three main domains by the north Armorican shear zone (NASZ) and the south Armorican shear zone (SASZ), two dextral crustal to lithosphericscale strike-slip faults (Fig. 2) (e.g. Gumiaux et al. 2004b). The northern domain is mostly made of Cadomian basement that belonged to the upper crust during Variscan orogeny (Ballèvre et al. 2001; Brun et al. 2001). The central domain is dominantly composed of Brioverian (Neoproterozoic-Cambrian) to Lower Carboniferous sediments that were mostly deformed under greenschist facies conditions during strike-slip deformation (Gumiaux et al. 2004a). Brioverian sediments in this domain constitute a more than $1000 \mathrm{~m}$ thick monotonous and immature detrital succession of wacke-type sandstones (Dabard et al. 1996). The Ordovician to Lower Carboniferous sediments form a heterogeneous mostly siliciclastic succession with a thickness above $3500 \mathrm{~m}$. Carbonates mostly occur in Devonian sediments whereas black shales are characteristic of the Silurian and the Upper Devonian (Pelhate 1994; Vidal et al. 2001). The 
southern domain, that belongs to the internal part of the Variscan belt, is characterized by an intense deformation and by the presence of high grade metamorphic rocks (e.g. Gapais et al. 2015). Three tectono-metamorphic units can be distinguished in this domain and comprise from top to bottom: (i) HP-LT rocks, composed of Ordovician acid metavolcanic rocks (Ballèvre et al. 2012) and blueschists subducted and exhumed between ca. 370 and $350 \mathrm{Ma}$ (e.g. Bosse et al. 2005), (ii) micaschists, and (iii) migmatite-bearing units (Fig. 2). Migmatites, mostly formed by partial melting of pre-Carboniferous sediments and Early Paleozoic orthogneisses and recorded peak P-T condition of $0.8 \mathrm{GPa}, 750-850{ }^{\circ} \mathrm{C}$ (Jones and Brown 1990; Augier et al. 2015).

Magmatism in the Armorican Massif occurred during four main periods. During the Cadomian period from ca. 750 to $580 \mathrm{Ma}$, the northern domain was affected by acid and mafic arc magmatism followed by voluminous granitoid plutonism at ca. 540 Ma (Ballèvre et al. 2001, 2013). In the Early Ordovician times (ca. 490 - $470 \mathrm{Ma}$ ), intracontinental rifting was responsible for the emplacement of tholeitic mafic magmas and voluminous acid metavolcanics (Vendée porphyroids) in the southern domain (Ballèvre et al. 2012), whereas Late CambrianEarly Ordovician granitoids intruded the whole massif (Fig. 2). The Devonian-Early Carboniferous period is marked by the emplacement of gabbros and various granitoids (Marcoux et al. 2009; Capdevila 2010) (Fig. 2) as well as by the development of an extensive network of mafic dikes at ca. $360 \mathrm{Ma}$ (Pochon et al. 2016). This period is related to Early Variscan subduction and initial collision. During the Late Carboniferous (from ca. 320 to 300 Ma), dextral wrenching of the central domain and crustal extension in the southern domain, led to the exhumation of migmatitic core complex (Gapais et al. 2015), coeval with the emplacement of three main types of granitoids (Fig. 2).

(1) MPGs: they were mostly emplaced either along extensional deformation zone in the internal domain of the Armorican Variscan belt, such as the Quiberon (Gapais et al. 2015) and 
Guérande (309.7 \pm 1.3 Ma: Ballouard et al. 2015a) MPGs, or along the SASZ such as the Questembert (316.1 +2.9 Ma: Tartèse et al. 2011b), Lizio (316.4 + 5.6 Ma: Tartèse et al. 2011a) and Pontivy (316.7 \pm 2.5 Ma: Ballouard et al. 2017b) MPGs. Some of them were also emplaced to the north of the SASZ such as the Langonnet (304.7 \pm 2.7 Ma: Ballouard et al. 2017b), Huelgoat (314.0 \pm 2.8 Ma: Ballouard 2016) and Saint-Renan MPGs (316.0 \pm 2.0 Ma: Le Gall et al. 2014). Previous isotopic studies (Bernard-Griffiths et al. 1985; Euzen 1993; Tartèse and Boulvais 2010; Ballouard et al. 2015a, 2017a, 2017b) revealed that these MPGs are characterized by high $\delta^{18} \mathrm{O}$ ratios (> 11), sub-chondritic to chondritic $\varepsilon \mathrm{Nd}(\mathrm{T})$ and elevated initial ${ }^{87} \mathrm{Sr} /{ }^{86} \mathrm{Sr}(>0.705)$ values in agreement with a crustal origin.

(2) CPGs: the Rostrenen (Euzen 1993; Ballouard et al. 2017b) and Huelgoat (Georget 1986) CPGs were emplaced at 315.5 $\pm 2.0 \mathrm{Ma}$ (Ballouard et al. 2017b) and 314.8 $\pm 2.0 \mathrm{Ma}$ (Ballouard 2016), respectively. These granites were emplaced synchronously with small stocks of mantlederived mafic to intermediate igneous rocks.

(3) KCGs: these metaluminous biotite \pm hornblende granitoids consist of a magnesiopotassic (Mg-K) and ferro-potassic (Fe-K) suite emplaced between 325 and $300 \mathrm{Ma}$ and associated with mantle-derived mafic to intermediate rocks (Peucat et al. 1984; Capdevila, 2010; Caroff et al. 2015; Ballouard et al. 2015b).

At a global scale, crustal partial melting to the south of the SASZ, during the Late Carboniferous, was triggered by lithospheric thinning during late orogenic extension. In contrast, to the north of the SASZ, partial melting of the crust and of a lithospheric mantle, metasomatized during previous subduction events, were likely induced by asthenosphere upwelling during diffuse strike-slip deformation of the central domain and subsequent slabtearing (Ballouard et al. 2017b). 
In the Armorican Massif, $\mathrm{U}$ was mostly mined in the district of Mortagne, Pontivy and

Guérande. In the Guérande and Pontivy districts, the MPGs were the main source for the U mineralization found in the intra to perigranitic vein and episyenite type hydrothermal deposits. Leaching of magmatic U oxides from the MPGs was promoted by the infiltration at depth of oxidized surface-derived hydrothermal fluids (Ballouard et al. 2017a, in press). U-Pb dating of U oxides from the Guérande, Pontivy and Mortagne district deposits reveal several mineralizing events that occurred by pulse from ca. 300 to $260 \mathrm{Ma}$ (Cathelineau et al. 1990; Ballouard et al. 2017a, in press).

\section{Samples and methods}

A description and the GPS coordinates of Late Carboniferous MPGs, sedimentary rocks, and Cambro-Ordovician granitoid samples selected for whole-rock major and trace element analyses as well as zircon $\mathrm{U}-\mathrm{Pb}$ and $\mathrm{Hf}$ isotope analyses are provided in Table 1 and Supplementary file 1.

MPGs selected for U-Pb (and $\mathrm{Hf}$ ) isotope analyses on inherited zircon grains include the $\mathrm{U}$ mineralized Guérande and Pontivy MPGs as well as the Questembert, Lizio, Langonnet and Hulgoats MPGs that are not spatially associated with U deposits (Fig. 2). Most sandstone or siltstone samples (Brioverian to Devonian) were collected in the region of Crozon in the western edge of the central Armorican domain (Fig. 2). In addition, a Lower Carboniferous (this study) and Devonian sandstone (Ducassou et al. 2014) were sampled in the Châteaulin basin (western part of the central domain, Fig. 2) and the Chalonnes region (eastern part of the central domain, Fig. 2), respectively. One metagranite (sample PLG-1), two metatonalites (samples PLG-2 and PLG-4) and one undeformed granite (sample PLG-3) from the Lower Paleozoic Plouguenast orthogneissic complex (central domain, Fig. 2), as well as one metatonalite (sample QIMP-1) from Moëlan (southern domain, Fig. 2) were also selected for zircon U-Pb dating. 


\section{Whole rock isotopic, major and trace element analyses}

Large samples (5 to $10 \mathrm{~kg}$ ) were crushed in the Geosciences Rennes Laboratory using agate mortars. Chemical analyses were performed by the Service d'Analyse des Roches et des Minéraux (SARM; CRPG-CNRS, Nancy, France) using a ICP-AES for the major elements and a ICP-MS for the trace elements following the techniques described in Carignan et al. (2001). The results of the analyses are provided in Supplementary file 2. Whole rock $\mathrm{Sr}$ and $\mathrm{Sm}-\mathrm{Nd}$ isotope analyses were performed at Geosciences Rennes, on two samples from the Guérande MPG (muscovite-tourmaline coarse grained facies, see Ballouard et al. 2015a) and one Lower Carboniferous sandstone sample from the Châteaulin Basin. The methodology and analytical conditions are described in Ballouard et al. (2017b) and the results of the isotope analyses are provided in Supplementary file 3.

\section{Zircon U-Pb and Hf isotope analyses}

A classical mineral separation procedure was applied to concentrate zircon grains using the facilities available at Geosciences Rennes (Ballouard et al. 2015a). Zircon grains were imaged by cathodoluminescence (CL) using a Reliotron CL system equipped with a digital color camera available at the Geosciences Rennes laboratory.

$\mathrm{U}-\mathrm{Pb}$ dating of zircon was performed by in-situ laser ablation inductively coupled plasma mass spectrometry (LA-ICP-MS) using a ESI NWR193UC Excimer laser coupled to a quadrupole Agilent 7700 x ICP-MS equipped with a dual pumping system to enhance sensibility. The methodology and analytical protocol used to perform the analyses can be found in Ballouard et al. (2015a) and Supplementary file 4. The analyses with a degree of concordance between 90 and $110 \%$ are provided in Supplementary file 5 with errors listed at $1 \sigma$. Histograms (50 Ma bins) and Kernel density estimates (KDE, $25 \mathrm{Ma}$ bands) of the zircon U-Pb dates were realized using the DensityPlotter software (Vermeesch 2012). ${ }^{206} \mathrm{~Pb} /{ }^{238} \mathrm{U}$ dates were used for 
zircon with a ${ }^{207} \mathrm{~Pb} /{ }^{206} \mathrm{~Pb}$ date $<1.0 \mathrm{Ga}$ whereas ${ }^{207} \mathrm{~Pb} /{ }^{206} \mathrm{~Pb}$ dates were used for zircon with a ${ }^{207} \mathrm{~Pb} /{ }^{206} \mathrm{~Pb}$ date $>1.0 \mathrm{Ga}$.

Hafnium (Hf) isotope analyses were performed at Goethe-University Frankfurt using a Thermo-Finnigan NEPTUNE multicollector ICP-MS coupled to a Resolution M-50 (Resonetics) $193 \mathrm{~nm}$ ArF Excimer laser (ComPexPro 102F, Coherent), using the procedure outlined in detail in Gerdes and Zeh $(2006,2009)$ and summarized in Supplementary file 4. The epsilon $\mathrm{Hf}$ values $[\varepsilon \mathrm{Hf}(\mathrm{t})]$ were calculated using the chondritic uniform reservoir (CHUR) as recommended by Bouvier et al. $\left(2008 ;{ }^{176} \mathrm{Lu} /{ }^{177} \mathrm{Hf}=0.0336\right.$ and $\left.{ }^{176} \mathrm{Hf} /{ }^{177} \mathrm{Hf}=0.282785\right)$ and a decay constant of $1.867 \times 10^{-11} \mathrm{yr}^{-1}$ (Scherer et al. 2001; Söderlund et al. 2004). The initial ${ }^{176} \mathrm{Hf} /{ }^{177} \mathrm{Hft}$, $\varepsilon \mathrm{Hf}(\mathrm{t})$ values and hafnium model ages $\left(\mathrm{T}_{\mathrm{DM}}\right)$ (for zircon grains with a degree of concordance between 90 and $110 \%$ ) were calculated using ${ }^{206} \mathrm{~Pb} /{ }^{238} \mathrm{U}$ ages for zircon with ${ }^{206} \mathrm{~Pb} /{ }^{207} \mathrm{~Pb}$ ages $<1.0 \mathrm{Ga}$ and ${ }^{206} \mathrm{~Pb} /{ }^{207} \mathrm{~Pb}$ ages for zircon with ${ }^{206} \mathrm{~Pb} /{ }^{207} \mathrm{~Pb}$ ages $>1.0 \mathrm{Ga}$. The result of analyses and additional information are provided in Supplementary file 6.

\section{Results}

\section{Geochemical features and $U$-Th distribution}

All investigated Late Carboniferous MPGs of the Armorican Massif are highly peraluminous and characterized by $\mathrm{A} / \mathrm{CNK}\left[\mathrm{Al}_{2} \mathrm{O}_{3} /\left(\mathrm{CaO}+\mathrm{Na}_{2} \mathrm{O}+\mathrm{K}_{2} \mathrm{O}\right)\right.$, molar proportions $]$ values > 1.1 (Fig. 3). However, the Huelgoat MPG plot on a different trend than the others MPGs, with relatively higher $\mathrm{A} / \mathrm{NK}$ values at low $\mathrm{A} / \mathrm{CNK}$ ratio, reflecting a higher $\mathrm{CaO}$ content. In Figure 4, these MPGs are mostly characterized by low and highly variable wholerock $\mathrm{Th} / \mathrm{U}$ ratio mostly from $\sim 0.1$ to 2 , as well as variable $\mathrm{U}$ content from 1 to $27 \mathrm{ppm}$.

The whole-rock composition of silicoclastic sediments and peraluminous igneous rocks representing potential source for the Late Carboniferous MPGs were also reported in the U versus Th diagram (Fig. 4). The U contents of the Brioverian and Paleozoic sediments 
(Ordovician to Devonian) range between $\sim 1$ and $7 \mathrm{ppm}$. However, the Paleozoic sediments generally show much higher $\mathrm{Th} / \mathrm{U}$ ratios (between $\sim 4$ and 7 ), i.e., above the average value of the upper continental crust (UCC 4), compared to most Brioverian sediments $(\mathrm{Th} / \mathrm{U}$ ratio mostly between $\sim 2$ and 4). Most Ordovician (meta)volcanics (Lower Paleozoic) are characterized by $\mathrm{U}$ contents between $\sim 1$ and $7 \mathrm{ppm}$ and variable $\mathrm{Th} / \mathrm{U}$ ratios between $\sim 2$ and 20 whereas Cambro-Ordovician (Lower Paleozoic) and Early Carboniferous (Pertre MPG) granitoids show more variable $\mathrm{U}$ contents between $\sim 2$ and $40 \mathrm{ppm}$ and are generally characterized by relatively low but variable Th/U ratios ranging from $\sim 0.5$ to 4 .

\section{Whole-rock Sr-Nd isotope data}

Most MPGs are characterized by elevated initial ${ }^{87} \mathrm{Sr} /{ }^{86} \mathrm{Sr}\left[\mathrm{I}_{\mathrm{Sr}}(315 \mathrm{Ma}]\right.$ ratios ranging from 0.706 (Pontivy MPG) and 0.719 (Guérande MPG) and negative $\varepsilon N d$ (315 Ma) values (-2.3 > $\varepsilon N d(315 \mathrm{Ma})>-8.0)$ with two stage $\mathrm{Nd}$ model ages $\left(\mathrm{T}_{\mathrm{DM}}\right)$ between 1.2 (Pontivy and Langonnet MPG) and 1.8 Ga (Guérande MPG, Fig. 5). However, two samples from the Pontivy MPG display super-chondritic $\varepsilon \mathrm{Nd}(315 \mathrm{Ma})$ values (1.2 and 2.2) with relatively low $\mathrm{I}_{\mathrm{Sr}}(0.704$ and 0.706) ratios and young $\mathrm{T}_{\mathrm{DM}}(1.0$ and $0.9 \mathrm{Ga})$. As noticed by Bernard-Griffiths et al. (1985), the $\mathrm{I}_{\mathrm{Sr}}(315 \mathrm{Ma})$ and $\varepsilon \mathrm{Nd}(315 \mathrm{Ma})$ values of MPG increase and decrease, respectively, from north to south with an evolution from the Pontivy-Langonnet-Lizio MPG, Questembert MPG to Guérande MPG (Figs. 2 and 5).

\section{$\mathrm{U}-\mathrm{Pb}$ dating}

\section{Inherited zircon from $M P G$}

Zircon grains from all investigated MPGs of the Armorican Massif are generally euhedral. They commonly show inherited cores surrounded by magmatic rims in CL images (Fig. 6). U$\mathrm{Pb}$ ages obtained on inherited zircon cores or grains from the MPGs are reported in form of histograms and KDE in Figure 7. In general, five ages populations can be distinguished which, 
however do not occur in all MPGs: (1) an Archean-Mesoproterozoic population at 3500-1400 Ma, (2) a Grenvillian population at $1200-900 \mathrm{Ma}$, (3) a Neoproterozoic population at $900-540$ Ma, (4) a Cambro-Ordovician population at 540-440 Ma and (5) a Silurian-Lower Carboniferous population at 440-330 Ma (Table 1). All MPG samples are dominated by zircon grains of the populations (3), (4) and (5). A significant amount of population (1) zircon occurs only in the Pontivy MPG (8\%), and of population (2) zircon in the Guérande MPG (8\%; see Fig. 7 and Table 1).

\section{Detrital zircon from sediments}

$\mathrm{U}-\mathrm{Pb}$ dates obtained on detrital zircon grains from the main sedimentary formations of the Armorican Massif are reported in Figure 8 and summarized in Table 1.

Zircon grains from the different sedimentary rocks show an euhedral to rounded shape and appear zoned or homogeneous in CL images (Fig. 6). The detrital grains reflect similar age populations (1 to 5) than the ones obtained from the xenocrysts in the MPGs (Table 1). However, the amount of Archean-to-Mesoproterozoic grains (population 1) is higher in the sediments compared to the MPGs, especially in Silurian and Devonian sediments (Fig. 8 and Table 1). The most significant difference is that some samples contain abundant zircon grains of Grenvillian age (population 2), e.g., the Silurian and Devonian sediments from Crozon (24$32 \%$ ), whereas they are completely absent or very scares in the Brioverian sandstone from Crozon (1\%) and the Lower Carboniferous sediments from Châteaulin (0\%). It is important to note that zircon age spectra similar to those of Silurian and Devonian sediments were obtained for an Ordovician sandstone from Crozon (Matteini et al. 2014). A minor Grenvillian population is also observed in the Devonian sandstone from Chalonnes (10\%; Fig. 8 and Table $1)$. 
Results of U-Pb dating reveal that the (meta)granitoids from Plouguenast and Moëlan (Fig. 2) intruded between $504.5 \pm 1.8$ (PLG-2) and 466.2 \pm 3.6 Ma (QIMP-1) - (for details see text and diagrams in Supplementary file 7), and that most of them contain inherited components (Fig. 9a and Table 1). Zircon shapes are euhedral to sub-euhedral, and CL images reveal welldeveloped grow zonation for most grains (Fig. 6). Xenocrystic zircon crystals in the (meta)granitoids overlap in age with the previously defined populations 1 (4\%) and 3 (18\%, Table 1). Zircon analyses with apparent Silurian to Devonian ages (7\%) are interpreted to result from $\mathrm{Pb}$ loss (see Supplementary file 7 for details).

The result of zircon U-Pb dating performed by Ballèvre et al. (2012) on acid peraluminous (meta)volcanics from the southern domain (Vendée Porphyroids, Fig. 2) are reported in Figure $9 \mathrm{~b}$ and Table 1 . These (meta)volcanics contains Neoproterozoic xenocrysts (6\%), belonging to the population 3 defined in the Late Carboniferous MPGs, whereas the Early Paleozoic grains (population 4: $93 \%$ ) brackets the age of intrusion from $494 \pm 4$ to $472 \pm 4$ Ma (Ballèvre et al. 2012). These ages are much older than those obtained on zircon grains from the Pertre MPG

(Vernhet et al. 2009) in the central domain (Fig. 2) that yield ${ }^{206} \mathrm{~Pb} /{ }^{238} \mathrm{U}$ ages between $362 \pm 2$ and $330 \pm 4 \mathrm{Ma}$ (population 5, $93 \%$ ) with a marked peak at ca. $340 \mathrm{Ma}$, interpreted to reflect the time of intrusion (Fig. 9c and Table 1) (Vernhet et al. 2009). One Neoproterozoic xenocryst belongs to the population 3 defined in the Late Carboniferous MPGs whereas two zircon grains with apparent ages of $323 \pm 3$ and $321 \pm 4 \mathrm{Ma}$, respectively, reflect Pb loss (Vernhet et al. 2009).

\section{Hf analyses}

The results of Hf isotope analyses on inherited zircon grains from MPGs are reported in a $\varepsilon \mathrm{Hf}(\mathrm{t})$ versus age diagram (Fig. 10a). The Hf isotope compositions of inherited zircon grains in all investigated MPGs are similar. The rare Archean-to- Paleoproterozoic grains (2890-1590 Ma) show superchondritic to subchondritic compositions $(\varepsilon \mathrm{Hf}(\mathrm{t})=3.9$ to -11.5$)$, whereas 
Mesoproterozoic-to-Carboniferous xenocrysts (1035-329 Ma) yield mostly superchondritic $\varepsilon \mathrm{Hf}(\mathrm{t})$ up to $+9.1(>60 \%)$. Superchondritic xenocrysts are predominant in the Pontivy $(-14.3$ to +8.3), Lizio (-4 to +8.2) and Langonnet (-10.3 to +8.4) MPGs, and mostly characterized by hafnium model ages $\left(\mathrm{T}_{\mathrm{DM}}\right)$ between 1.6 and $0.9 \mathrm{Ga}$. In contrast, the Questembert MPG (-12.1 to 7) is dominated by subchondritic grains, even though most of them also show $\mathrm{T}_{\mathrm{DM}}$ between 1.6 and 0.9 Ga. Then, zircon grains from the Guérande MPG (-14.2 to 9.1) show a wide and relatively continuous range of $\varepsilon \mathrm{Hf}(\mathrm{t})$ from sub- to superchondritic (Fig. 10a). About $70 \%$ of zircon are characterized by $\mathrm{T}_{\mathrm{DM}}$ between 1.6 and $0.9 \mathrm{Ga}$ whereas others show older $\mathrm{T}_{\mathrm{DM}}$ between 1.60 and $2.3 \mathrm{Ga}$.

The $\varepsilon H f(t)$ values of detrital zircon grains from the Brioverian and Lower Carboniferous sediments shows a remarkable overlap with those of the MPGs (Figs. 10b and 10d): ArcheanMesoproterozoic zircon grains (3080-1430 Ma) show $\mathrm{T}_{\mathrm{DM}}$ from 3.7 to $2.2 \mathrm{Ga}$ and about $75 \%$ of the Neoproterozoic-Carboniferous grains (851-329 Ma) are characterized by $\mathrm{T}_{\mathrm{DM}}$ between and 1.6 and $0.9 \mathrm{Ga}$. In contrast, detrital zircon grains in the Silurian and Devonian sedimentary rocks show significantly different Mesoproterozoic-to-Cambrian $\varepsilon \mathrm{Hf}(\mathrm{t})$ spectra characterized by a wide range in $\varepsilon \mathrm{Hf}(\mathrm{t})$ at $1200-900 \mathrm{Ma}\left(-38\right.$ to $\left.+10.8 ; \mathrm{T}_{\mathrm{DM}}=3.8-1.2 \mathrm{Ga}\right)$, and by about $70 \%$ of subchondritic $\mathrm{eHf}(\mathrm{t})$ for ages $<900 \mathrm{Ma}\left(-37\right.$ to $+8 ; \mathrm{T}_{\mathrm{DM}}=3.6-1.1 \mathrm{Ga}$; Fig. 10b). This difference is also reflected by the generally much older Hf model ages for the Neoproterozoicto-Cambrian population, with more than $50 \%$ between 1.6 and $2.5 \mathrm{Ga}$ (Fig. 10b). The Hf isotopic data of the Archean-to-Paleoproterozoic grains (2922-1841 Ma; $\left.\mathrm{T}_{\mathrm{DM}}=3.5-2.5 \mathrm{Ga}\right)$ in the Silurian-Devonian sediments overlap with those in the Brioverian-Carboniferous sediments and in the MPGs.

The $\varepsilon H f(t)$ values of magmatic zircon grains from the Cambro-Ordovician metaigneous rocks (510-460 Ma) vary from -0.7 to +14.2 , corresponding to hafnium model ages between 1.4 and $0.6 \mathrm{Ga}$ (Fig. 10c). It is pertinent to note, that these $\mathrm{T}_{\mathrm{DM}}$ overlap with those obtained 
from most Neoproterozoic-to Carboniferous xenocrysts in the MPGs (Figs. 10a and 10d).

However, there is also an important number of grains showing significantly higher $\varepsilon \mathrm{Hf}(\mathrm{t})$, very close to the depleted mantle. Such grains were mostly found in sample PLG-1 from the Plouguenast orthogneissic complex (Fig. 10c).

\section{Discussion}

\section{Pre- to Early Variscan zircon record}

Neoproterozoic to Early Cambrian zircon grains (850 - 530 Ma, Fig. 7a) in the Brioverian sediments likely result from magma mixing, which occurred during the formation of the Cadomian-Avalonian belt, an Andean-type cordillera located at the northern margin of Gondwana, e.g. to the north of the Armorican Massif (Fig. 2a), between approximately 800 and 540 Ma (e.g. Nance and Murphy 1994; Dabard et al. 1996; Ballèvre et al. 2001; Brun et al. 2001; Zeh et al. 2001; Linnemann et al. 2008, 2014; Koglin et al. 2018). This hypothesis is supported by the vertical array in the $\varepsilon \mathrm{Hf}(\mathrm{t}) v s$. age diagram (array CA in Figure 10d), reflecting the interaction of crustal melts formed by reworking of Archean-to-Paleoproterozoic crust of the West Africa craton ( $\varepsilon \mathrm{Hft}$ down to -22$)$, and mantle-derived melts $(\varepsilon H \mathrm{ft}$ up to +13$)$. Then, most Archean-to-Mesoproterozoic zircon grains (3080 - 1430 Ma; Fig. 8a) likely originated from the erosion of the West African craton (Fig. 10d), that represented the hinter land of the Cadomian orogeny (e.g. Zeh et al. 2001; Linnemann et al. 2008, 2014), whereas the ca. 2000 Ma old Icartian orthogneisses (e.g. Samson and D’Lemos 1998) only represented a minor source (e.g. Dabard et al. 1996).

The Silurian and Devonian sediments might result from internal reworking of a very heterogeneous Grenvillian crust (indicated by the vertical array G in Fig. 10d), with minor contribution from the Cadomian-Avalonian crust. The Grenville zircon grains are very likely to be derived from a southern Gondwana-connected source, whereas a northern Baltica 
provenance can be excluded. Indeed, Grenvillian zircon populations were found in many Paleozoic sediments throughout the EVB, commonly associated with a predominant Neoproterozoic-Cambrian (800-500 Ma), and a subordinate Archean-to-Palaeoproterozoic zircon population (1700-3500 Ma), and with a pronounced age gap between 1.2 and $1.7 \mathrm{Ga}$ (e.g. Zeh et al. 2001; Linnemann et al. 2008, 2014). In fact, these are the same features observed in the Armorican sediments during this study (Fig. 10b). In contrast, zircon grains derived from Baltica, have ages mostly between 1.0 and $1.8 \mathrm{Ga}$, as it has been demonstrated for Paleozoic (meta)sediments from the Rhenohercynian Domain (Avalonia-Laurussia in Fig. 1), and the Mid-German Crystalline Zone (northwestern edge of the Saxo-Thuringian in Fig. 1) of the eastern EVB (Geisler et al. 2005; Zeh and Gerdes 2010).

The overlap in zircon Age-Hf isotopic data suggests that the Cambro-Ordovician (meta)granitoids of the Armorican Massif were predominantly formed by partial melting of Brioverian sediments (Fig. 10d). However, the highly superchrondritic $\varepsilon \mathrm{Hf}(\mathrm{t})$ (near to depleted mantle) signature of some zircon grains from the granitoids of the Plouguenast orthogneissic complex additionally reveals that new (juvenile) crust was formed at the same time. In this context it is pertinent to note that Cambro-Ordovician juvenile crust formation (in addition to crustal melting) is not restricted to the Armorican Massif (e.g. Bernard-Griffiths et al. 1986; Ballèvre et al. 2012) but has been reported from many other areas throughout the EVB, e.g., from the NW Iberian Massif (e.g. Arenas et al. 2016), French Massif Central (e.g. ChelleMichou et al. 2017) and Saxothuringian Domain (e.g. Bankwitz et al. 1994; Höhn et al. 2017), where it is related to the breakup of continental microterranes from the northern Gondwanan margin (e.g. Kroner and Romer 2013). The relatively wide variation in $\mathrm{\varepsilon Hf}(\mathrm{t})$ of the CambroOrdovician metaigneous rocks (array R in Fig. 10d) is ambiguous. It could be explained by heterogeneities of the source (Brioverian sediments), but, more probably, by mixing of juvenile 
melts (depleted mantle-related) and crustal-derived melts, formed by the partial melting of Brioverian sediments.

The Age-Hf-isotopic data furthermore suggest that the Brioverian sediments and the Cadomian-Avalonian basement together with Cambro-Ordovician igneous rocks were the main sources for the detrital zircon grains in the Lower Carboniferous sediments (Fig. 10b). Moreover, a significant addition from zircon grains derived from Early Variscan granitoids emplaced between 400 and $330 \mathrm{Ma}$ (array EV in Fig. 10d) such as the ca. 340 Ma old Pertre granite (Fig 9c), is revealed by isotopic data. Most 390 to 330 Ma old zircon grains in the Lower Carboniferous sediments are characterized by $\mathrm{T}_{\mathrm{DM}}$ from 1.2 to $1.6 \mathrm{Ga}$ that overlap with those of Neoproterozoic zircon in the Brioverian sediments (Figs 10b and d), suggesting that these zircon grains crystallized in a crustal-derived granitic magma formed by the partial melting of Brioverian sediments. This hypothesis is in agreement with the presence of a ca. $625 \mathrm{Ma}$ old zircon xenocryst in the Pertre granite (Fig. 9c, Table 1).

\section{Crustal sources of Late Carboniferous MPGs}

The highly peraluminous character (A/CNK > 1.1, Fig. 3) of the MPGs is in agreement with a crustal origin and suggest that they were produced by the partial melting of mica-rich rocks with a peraluminous composition (e.g. Gao et al. 2016).

Whole-rock $\mathrm{Nd}$ and $\mathrm{Sr}$ isotope analyses indicate a significant difference in composition between the MPGs emplaced to the north of the SASZ (i.e. Pontivy, Langonnet, Lizio) and the Guérande MPG intruded to south of the SASZ (Figs. 2 and 5). The Questembert MPG, which emplaced between the two branches of the SASZ, has an intermediate composition. The negative $\varepsilon \mathrm{Nd}(315 \mathrm{Ma})$ values of the Guérande MPG (-7.6 to -9.5$)$ could be explained by the partial melting of Cambro-Ordovician acid (meta)volcanic rocks as well as Ordovician to Devonian sediments from the south Armorican domain, although some samples plot at the 
lower boundary of the range defined by Brioverian sediments from the central domain (Fig. 5). The $\varepsilon N d(315 \mathrm{Ma})$ values of the Questembert MPG (-3.9 to -5.7) overlap with those obtained from the Brioverian sediments from the central domain as well as with Cambro-Ordovician acid (meta)volcanic rocks. Then, the composition of the Pontivy, Langonnet and Lizio MPGs (-2.3 to -4.7) is similar to that of Brioverian sediments from the central domain as well as the CambroOrdovician (meta)granitoids and (meta)volcanic rocks. The super-chondritic $\varepsilon \mathrm{Nd}(315 \mathrm{Ma})$ composition of two Pontivy MPG samples could be explained by the partial melting of CambroOrdovician (meta)granitoids. However, the $\mathrm{Nd}$ isotopic values on their own are ambiguous, and do not allow a detailed source characterization. Two reasons may be proposed at this stage. First, the MPG melts can be derived from several sources and, second, some sources show a wide range in $\varepsilon N d$ values (Fig. 5), e.g., the Cambro-Ordovician acid (meta)volcanics rocks, which themselves were formed by melting of even older crustal components such as Brioverian sediments (Ballèvre et al. 2012).

Combined U-Pb and Hf isotopic data of zircon xenocrysts (2890-329 Ma; Table 1; Figs. 7 and 10d) suggest that the Late Carboniferous MPGs were formed by partial melting of a heterogeneous crust mainly consisting of Brioverian sediments, Cambro-Ordovician acid igneous rocks and Devonian to Early Carboniferous granitoids. In contrast, Ordovician to Devonian sedimentary rocks seems to play only a subordinate role during U-fertile MPGs formation for several reasons. First, they contain an important Grenvillian population (1.2-0.9 Ma: this study, Matteini et al. 2014) with a wide range in $\varepsilon H f(t)$ (-38 to 10.8), which is barely seen in the xenocrysts from the MPGs (Fig. 10d). The only exceptions are four grains (8\%) in the Guérande MPG and one grain in the Lizio (3\%) and Pontivy (1\%) MPGs, respectively (Table 1, Figs 7). Second, the Silurian and Devonian sediments contain a pronounced Archean to Mesoproterozoic population (3.5-1.4 Ga; 23-36\%) which is not observed in the MPGs (< 10\%, Table 1). Third, detrital zircon grains from Silurian to Devonian sediments with ages < 
0.9 Ga mostly show subchondritic $\varepsilon \mathrm{Hf}(\mathrm{t})$ values (ca. 70\%), corresponding to Hf model ages of 2.5 to $1.6 \mathrm{Ga}$, which are much older than those of most MPGs (0.9 to $1.6 \mathrm{Ga})$. On the other hand, a significant number of Neoproterozoic to Carboniferous (750-329 Ma) zircon with old $\mathrm{T}_{\mathrm{DM}}$ from 1.6 to $2.5 \mathrm{Ga}$ (Fig. 10a) together with some Grenvillian grains (1080-974 Ma; Fig. 7f) in the Guerande MPG suggests a minor contribution of Ordovician to Devonian sediments in its source, in agreement with its high sub-chondritic $\varepsilon N d$ composition (Fig. 5). Moreover, the contribution of Lower Carboniferous sediments in the source of all MPGs is unlikely and difficult to explain structurally. Indeed, the central domain that was mainly deformed under strike-slip deformation regime during the Carboniferous was poorly thickened during the Variscan orogeny (Gumiaux et al. 2004a; Gapais et al. 2015) and the burying, and subsequent partial melting, of Lower Carboniferous sediments probably never occurred in the central domain. Then, it is unlikely that important partial melting of the Lower Carboniferous sediments occurred in the region without partial melting of Ordovician to Devonian sediments that are structurally below. Alternatively, the partial melting of the Devonian to Early Carboniferous granitoids such as the 391-385 Ma old peraluminous Plounévez-Lochrist orthogneiss (Marcoux et al. 2009) (Fig. 2) can explain the younger range of inheritance observed in all the MPGs (population 5, Table 1). Finally, metatexites and diatexites derived from pre-Carboniferous sediments and Ordovician orthogneisses are abundant in the southern Armorican domain (e.g. Augier et al. 2015) (Fig. 2). These rocks reached peak P-T conditions of $0.8 \mathrm{GPa}, 750-850{ }^{\circ} \mathrm{C}$ followed by near isothermal decompression down to $0.4 \mathrm{GPa}, 750{ }^{\circ} \mathrm{C}$ and melting occurred, during the Late Carboniferous, from water saturated solidus to biotite breakdown conditions (Augier et al. 2015; Jones and Brown, 1990), in agreement with the role of Brioverian sediments and Paleozoic orthogneisses as a major source for the MPGs.

\section{Implication for the U-fertility of MPGs}


The results of this study show that the U-fertile Pontivy and Questembert MPGs, and the U-unfertile Lizio, Langonnet and Hulgoat MPGs, all emplaced to the north of the southern branch of the SASZ, result from the melting of the same heterogeneous crust, which consisted of Brioverian sediments, Cambro-Ordovician acid igneous rocks and Devonian-toCarboniferous granitoids. Similar hafnium model ages furthermore suggest that all these rocks are genetically linked, and result from the successive internal reworking of Brioverian sediments (Fig. 10d). Age-Hf isotopic data also suggest that the U-fertile Guérande MPG, emplaced to the south of the SASZ, result from the partial melting of a similar crust with only a minor contribution from Ordovician to Devonian sediments.

Thus, fertility or non-fertility of the Late Carboniferous MPGs from the Armorican Massif is obviously controlled primarily by differences during the reworking process, comprising local variations of source rocks (sediment vs. orthogneiss), degree of melting and fractionation, and the melting history itself (unique or multiple), as well as hydrothermal processes during and after each magmatic cycle. The complex interplay of all these processes has been demonstrated by recent studies suggesting that the Lizio and Questembert MPGs represent "twin" leucogranites but that the Questembert MPG is more differentiated than the Lizio MPG because the former traveled a greater vertical distance in the crust, enhancing crystal segregation from the melts and $U$ enrichment in the residual liquids (Tartese and Boulvais 2010; Tartèse et al. 2013). sedimentary and/or igneous sources. However, the proportion of U located outside the lattice of accessory minerals poorly soluble in peraluminous melts, such as zircon and monazite (Watson and Harrison 1983; Montel 1993), has a primordial importance for the genesis of Ufertile MPGs (e.g. Cuney 2014). In the absence of a detailed petrographic study, the whole-rock 
rich melts during anatexis. High $\mathrm{Th} / \mathrm{U}$ ratios, above the average value of the upper continental crust $(\mathrm{UCC}$ Th/U value $=3.8$, Rudnick and Gao 2003), suggest that most $\mathrm{U}$ is hosted in Thbearing, highly refractory, minerals such as monazite (xenotime and zircon), whereas $\mathrm{Th} / \mathrm{U}$ ratios $<3.8$ suggest that a significant amount of $U$ is localized along microcracks or in adsorption on the surfaces of rock forming minerals. In most favorable cases, peraluminous igneous rocks with $\mathrm{Th} / \mathrm{U}<1$ and $\mathrm{U}$ contents $>\sim 10$ ppm can host $\mathrm{U}$ oxides (Peiffert et al. 1996, 1994). By taking these points into account, we suggest that the U-fertile MPGs $(\sim 0.1<\mathrm{Th} / \mathrm{U}<$ 2, Fig. 4) of the Armorican Massif were formed by partial melting of peraluminous mica-rich lithologies characterized by $\mathrm{Th} / \mathrm{U}<\sim 4$ and $\mathrm{U}$ content $>\sim 2.7 \mathrm{ppm}$ (average UCC values). Such rocks comprise the Brioverian sediments, but also Cambro-Ordovician and Devonian-Early Carboniferous peraluminous igneous rocks (Fig. 4). In contrast, the Ordovician to Devonian sediments and Cambro-Ordovician acid volcanic rocks with $\mathrm{Th} / \mathrm{U}>4$ and $\mathrm{U}<2.7 \mathrm{ppm}$, can be considered as less fertile. Our new data also suggest that U-fertility of a crust increases if oneand-the same (peraluminous) crust is affected by multiple melting events, which obviously occurred in the Armorican Massif during the internal reworking of already U-rich (low Th/U) Brioverian sediments during the Cambro-Ordovician, Devonian-Lower Carboniferous and finally during the Upper Carboniferous, in particular along or close to the crustal to lithospheric scale shear zones. More specifically, multiple crustal reworking can induce progressive U enrichment of some crustal domains (i.e. middle crust) and in late orogenic context, the melting of these domains can lead to the formation of U-fertile granites. These interpretations are in good agreement with the fact that peraluminous orthogneisses of Cambro-Ordovician, and Devonian-Early Carboniferous ages occur in the source regions of nearly all Late Carboniferous MPGs throughout the EVB, comprising the French Massif Central (Turpin et al. 1990; Laurent et al. 2017), the Iberian Massif (e.g. Villaseca et al. 2012 ; López-Moro et al. 2017), and the Bohemian Massif in Germany and the Czech Republic (Tichomirowa et al. 2012), three 
historical mining provinces for granite-related hydrothermal U deposits (Fig. 1). In this context, it is interesting to note that, the Cambro-Ordovician Saint-Goueno MPG from the Plouguenast orthogneissic complex in the Armorican Massif (Fig. 2) hosts intragranitic U occurrences (Carric et al., 1980), suggesting that it contained magmatic U oxides, and reached U-fertility long before the Variscan orogeny.

\section{Comparison with other uraniferous provinces worldwide}

In the Armorican Variscan belt, multiple partial melting of the crust is associated with progressive increase of the U-fertility of crustal-derived granitoids with time (Fig. 4). This is revealed by, in general, a progressive decrease of the $\mathrm{Th} / \mathrm{U}$ ratio from the Brioverian sediments $(\sim 2<\mathrm{Th} / \mathrm{U}<\sim 4)$, Cambrian-Early Carboniferous granitoids $(\sim 0.5<\mathrm{Th} / \mathrm{U}<\sim 4)$ to Late Carboniferous MPGs $(\sim 0.1<\mathrm{Th} / \mathrm{U}<\sim 2)$. To see if this behavior can be generalized to other crustal domains, we report in Figure 11 the evolution of the Th-U contents of granitoids from two major U provinces for comparison, from:

(1) the Archean Gabonese craton that surrounds the Paleoproterozoic Franceville basin, well known for hosting $\mathrm{U}$ deposits with natural fission reactors such as Oklo. Ultimately, the $\mathrm{U}$ from the deposits likely originates from the leaching of U-rich minerals present in the basin, such as monazite, thorite and possibly uraninite, themselves coming from the erosion of the surrounding Archean basement (e.g. Gauthier-Lafaye and Weber 2003). In the basement, granitoid plutonism occurred from 2.94 to $2.71 \mathrm{Ga}$ with an evolution from TTG gneiss, grey granitoids, pink granitoids to Neoarchean granites and pegmatites (Thiéblemont et al. 2009).

(2) the Mesoproterozoic western Namaqualand province, South Africa, representing a granulite- to amphibolite-facies metamorphic terrane characterized by the presence of granites and charnokites highly enriched in $U$ and Th (Andreoli et al. 2006). In the 
region, crustal-derived granitic magmatism occurred over a period of ca. $200 \mathrm{Ma}$ (Robb et al. 1999).

Despite the different degree of enrichment, by one order of magnitude, the $U$ (and $\mathrm{Th}$ ) contents of the granitoids from both provinces increase progressively and significantly with time. In the Gabonese craton, $\mathrm{U}$ increase from $\sim 0.1-0.2 \mathrm{ppm}$ (TTG), $\sim 0.2-1 \mathrm{ppm}$ (grey granitoids) to $\sim 1-4 \mathrm{ppm}$ (pink granites), and in the Namaqualand province, from $\sim 1-10 \mathrm{ppm}$ (Little Namaqualand suite), 3-60 ppm (Early Spektakel suite) to 3-800 ppm (Late Spektakel suite). In the two provinces, fractionation of $\mathrm{U}$ over Th, a process that can lead, ultimately, to the crystallization of magmatic uraninite (Cuney, 2014), is only recorded by the youngest granites and pegmatites (Neoarchean granites and pegmatites in Fig. 11a and granites of the Late Spektakel suite in Fig. 11b). To summarize, the recycling of the crust by multiple partial melting events seems to be an important mechanism for the concentration of $\mathrm{U}$, the fractionation of $\mathrm{U}$ over Th, and finally for the genesis of U-fertile granites.

\section{Conclusion}

(1) Age-Hf isotopic data of detrital zircon grains in Brioverian to Carboniferous sediments, magmatic and inherited zircon crystals in Cambrian to Early Carboniferous (meta)igneous rocks, and xenocrysts in the Late Carboniferous MPGs indicate that the crust of the Armorican Massif is made up by detritus derived from three major sources: West African craton $\left(3500-1600 \mathrm{Ma} ; \mathrm{T}_{\mathrm{DM}}=3.8\right.$ to $\left.2.2 \mathrm{Ga}\right)$, Grenville belt/domains $\left(1200-900 \mathrm{Ma} ; \mathrm{T}_{\mathrm{DM}}\right.$ $=2.7$ to $1.2 \mathrm{Ga})$, and predominately Avalonian-Cadomian belt $\left(800-550 \mathrm{Ma}\right.$; $\mathrm{T}_{\mathrm{DM}}=2.5$ to $0.8 \mathrm{Ga}$ ). Moreover, the crust was affected by magmatic events at 510-460 Ma (CambroOrdovician; $\mathrm{T}_{\mathrm{DM}}=1.6$ to $\left.0.6 \mathrm{Ga}\right), 410-330 \mathrm{Ma}$ (Devonian-Carboniferous; $\mathrm{T}_{\mathrm{DM}}=2.1$ to 1.0 Ga), and 320-300 Ma (Late Carboniferous). 
(2) These data also reveal that the Late Carboniferous MPGs (300-320Ma) were mainly formed by partial melting of Brioverian sediments, Cambro-Ordovician igneous rocks and Devonian-Early Carboniferous granitoids, which are all genetically linked with each other, as is indicated by a remarkable overlap in their Hf model ages between 1.6 to $0.8 \mathrm{Ga}$. In contrast, Ordovician, Silurian and Devonian sediments of the Armorian Massif contain a significant Grenvillian zircon population $(\sim 30 \%)$ with mostly older Hf model ages between 1.6 and $2.5 \mathrm{Ga}$, which are barely seen in the Late Carboniferous MPGs (Huelgoat, Langonnet, Pontivy, Lizio and Questembert), except for a minor amount in the Guérande $\operatorname{MPG}(\sim 10 \%)$.

(3) In contrast to Ordovician to Devonian sediments (Th/U > 4), Brioverian sediments and Cambrian to Early Carboniferous granitoids characterized by $\mathrm{U}>2.7 \mathrm{ppm}$ and $\mathrm{Th} / \mathrm{U}<4$ represent an ideal source for the generation of U-fertile MPGs.

(4) All data suggests that the U-fertile MPGs of the Armorican Massif result mainly from multiple internal reworking of relatively U-rich Brioverian sediments, which were originally deposited along the northern Gondwanan margin at ca. $550 \mathrm{Ma}$, and became partially molten during several Paleozoic events, causing a successive increase in Ucontent by crystal fractionation, and intermediate hydrothermal processes in the middleupper crust. Similar multiple, internal reworking processes of Neoproterozoic-Cambrian sediments is recorded by rocks from many areas across the EVB hosting economically important U deposits, such as Iberia, French Massif Central and Bohemian Massif.

(6) Comparison with other U provinces of different ages worldwide suggest that crustal reworking by multiple partial melting events is a major mechanism for $\mathrm{U}$ concentration, fractionation of $\mathrm{U}$ over $\mathrm{Th}$, and the genesis of U-fertile granites. 
This work was supported by the 2012-2013 NEED-CNRS (AREVA-CEA) and 2015CESSUR-INSU (CNRS) grants attributed to M. Poujol. We are very grateful to M.P. Dabard as well M. Jolivet, R. Tartèse and P. Bessin who helped for the sampling. We also want to thanks Y. Lepagnot and D. Vilbert (Geosciences Rennes) for crushing the samples and realizing whole-rock radiogenic isotope analyses ( $\mathrm{Sm}-\mathrm{Nd}$ and $\mathrm{Sr}$ ), respectively. Comments from $\mathrm{C}$. Villaseca and A.S. André-Mayer significantly improved the quality of the manuscript. Finally, this study is dedicated to the memory of M.P. Dabard who left us too early.

\section{References}

Andreoli MAG, Hart RJ, Ashwal LD, Coetzee H (2006) Correlations between U, Th Content and Metamorphic Grade in the Western Namaqualand Belt, South Africa, with implications for radioactive heating of the crust. J Petrol 47: 1095-1118

Augier R, Choulet F, Faure M, Turrillot P (2015) A turning-point in the evolution of the Variscan orogen: the ca. 325 Ma regional partial-melting event of the coastal South Armorican domain (South Brittany and Vendée, France). Bull Société Géologique Fr 186: 63-91

Arenas R, Sánchez Martínez S, Díez Fernández R, Gerdes A, Abati J, Fernández-Suárez J, Andonaegui P, González Cuadra P, López Carmona A, Albert R, Manuel Fuenlabrada J, Rubio Pascual FJ (2016) Allochthonous terranes involved in the Variscan suture of NW Iberia: A review of their origin and tectonothermal evolution. Earth-Sci Rev 161: 140-178

Bailie R, Armstrong R, Reid D (2007) The Bushmanland Group supracrustal succession, Aggeneys, Bushmanland, South Africa: Provenance, age of deposition and metamorphism. South Afr J Geol 110: 59-86 
Ballèvre M, Martínez Catalán JR, López-Carmona A, Pitra P, Abati J, Díez Fernández R, Ducassou C, Arenas R, Bosse V, Castiñeiras P, Fernández-Suárez J, Gómez Barreiro J, Paquette JL, Peucat JJ, Poujol M, Ruffet G, Sánchez Martínez S (2014) Correlation of the nappe stack in the Ibero-Armorican arc across the Bay of Biscay: a joint French-Spanish project. Geol Soc London Spec Publ 405: 77-113

Ballèvre M, Bosse V, Dabard MP, Ducassou C, Fourcade S, Paquette JL, Peucat JJ, Pitra, P (2013) Histoire géologique du Massif armoricain: actualité de la recherche. Bulletin de la Société géologique et minéralogique de Bretagne 500: 5-96.

Ballèvre M, Fourcade S, Capdevila R, Peucat JJ, Cocherie A, Fanning CM (2012) Geochronology and geochemistry of Ordovician felsic volcanism in the Southern Armorican Massif (Variscan belt, France): Implications for the breakup of Gondwana. Gondwana Res 21: 1019-1036

Ballèvre M, Bosse V, Ducassou C, Pitra, P (2009) Palaeozoic history of the Armorican Massif: Models for the tectonic evolution of the suture zones. Comptes Rendus Geosci 341: 174-201

Ballèvre M, Le Goff E, Hébert R (2001) The tectonothermal evolution of the Cadomian belt of northern Brittany, France: a Neoproterozoic volcanic arc. Tectonophysics 331: 19-43

Ballouard C (2016) Origine, évolution et exhumation des leucogranites peralumineux de la chaîne hercynienne armoricaine: implication sur la métallogénie de l'uranium. Dissertation, Université de Rennes 1

Ballouard C, Poujol M, Mercadier J, Deloule E, Boulvais P, Cuney M, Cathelineau M (in press) Uranium metallogenesis in the peraluminous leucogranites from the Pontivy-Rostrenen magmatic complex (French Armorican Variscan Belt): the result of long term oxidized 
648

649

650

651

652

653

654

655

656

657

658

659

660

661

662

663

664

665

666

667

668

669

hydrothermal alteration during strike-slip deformation. Miner deposita. DOI : 10.1007/s00126017-0761-5

Ballouard C, Poujol M, Boulvais P, Zeh A (2017b) Crustal recycling and juvenile addition during lithospheric wrenching: The Pontivy-Rostrenen magmatic complex, Armorican Massif (France), Variscan belt. Gondwana Res 49: 222-247

Ballouard C, Poujol M, Boulvais P, Mercadier J, Tartèse R, Venneman T, Deloule E, Jolivet M, Kéré I, Cathelineau M, Cuney M (2017a) Magmatic and hydrothermal behavior of uranium in syntectonic leucogranites: The uranium mineralization associated with the Hercynian Guérande granite (Armorican Massif, France). Ore Geol Rev 80: 309-331

Ballouard C, Poujol M, Jolivet M, Boulvais P, Tartese R, Dubois C, Hallot E, Dabard MP, Ruffet G (2015b) Geochronological and thermochronological constraints on the Carboniferous magmatism from the Armorican Massif: from the source to the exhumation. The Variscan Belt: Correlations and Plate Dynamics, Variscan Conference 2015, Rennes (France), 9-11 June 2015

Ballouard C, Boulvais P, Poujol M, Gapais D, Yamato P, Tartèse R, Cuney M (2015a) Tectonic record, magmatic history and hydrothermal alteration in the Hercynian Guérande leucogranite, Armorican Massif, France. Lithos 220-223: 1-22

Bankwitz P, Bankwitz E, Kramer W, Pin C (1994) Early Paleozoic bimodal volcanism in the Vesser area, Thuringian Forest, eastern germany. Z Geol Paläontol I 1992: 1113-1132

Barbarin B (1996) Genesis of the two main types of peraluminous granitoids. Geology 24: 295298

Barbarin B (1999) A review of the relationships between granitoid types, their origins and their geodynamic environments. Lithos 46: 605-626 
Béchennec F, Hallégouët B, Thiéblemont D (2001) Rosporden 347, Carte Géologique de

672 France 1:50 000. BRGM

673 Béchennec F, Hallégouët B, Thiéblemont D (1999) Quimper 346, Carte Géologique de France $674 \quad 1: 50$ 000. BRGM

675 Béchennec F, Guennoc P, Guerrot C, Lebret P, Thiéblemont D (1996) Concarneau 382, Carte 676 Géologique de France 1:50 000. BRGM

677 Bernard-Griffiths J, Carpenter MSN, Peucat JJ, Jahn BM (1986) Geochemical and isotopic 678 characteristics of blueschist facies rocks from the Île de Groix, Armorican Massif (northwest 679 France). Lithos 19: 235-253

680

681

682

683

684

685

686

687

688

689

Bernard-Griffiths J, Peucat JJ, Sheppard S, Vidal P (1985) Petrogenesis of Hercynian leucogranites from the southern Armorican Massif: contribution of REE and isotopic ( $\mathrm{Sr}, \mathrm{Nd}$, $\mathrm{Pb}$ and $\mathrm{O}$ ) geochemical data to the study of source rock characteristics and ages. Earth Planet Sci Lett 74: 235-250

Bosse V, Féraud G, Ballèvre M, Peucat JJ, Corsini M (2005) Rb-Sr and ${ }^{40} \mathrm{Ar} /{ }^{39} \mathrm{Ar}$ ages in blueschists from the Ile de Groix (Armorican Massif, France): Implications for closure mechanisms in isotopic systems. Chem Geol 220: 21-45

Bouvier A, Vervoort JD, Patchett PJ (2008) The Lu-Hf and Sm-Nd isotopic composition of CHUR: Constraints from unequilibrated chondrites and implications for the bulk composition of terrestrial planets. Earth Planet Sci Lett 273: 48-57 
690

691

692

693

694

695

696

697

698

699

700

701

702

703

704

705

706

707

708

709

710

Bouton P, Thiéblemont D, Gouin J, Moussavou M (2009) Notice explicative de la Carte géologique de la République du Gabon à 1: 200 000, Feuille Franceville - Boumango, Editions DGMG - Ministères des Mines, du Pétrole, des Hydrocarbures. Libreville

Brun JP, Guennoc P, Truffert C, Vairon J (2001) Cadomian tectonics in northern Brittany: a contribution of 3-D crustal-scale modelling. Tectonophysics 331: 229-246

Capdevila R (2010) Les granites varisques du Massif Armoricain. Bulletin de la Société Géologique et Minéralogique de Bretagne 7: 1-52

Carignan J, Hild P, Mevelle G, Morel J, Yeghicheyan D (2001) Routine Analyses of Trace Elements in Geological Samples using Flow Injection and Low Pressure On-Line Liquid Chromatography Coupled to ICP-MS: A Study of Geochemical Reference Materials BR, DRN, UB-N, AN-G and GH. Geostand Newsl 25: 187-198

Carric G, Chantraine J, Dadet P, Flageollet JC, Sagon JP, Talbot H (1980) Montcontour 279, Carte géologique de France 1: 50 000. BRGM

Caroff M, Labry C, Le Gall B, Authemayou C, Grosjean DB, Guillong M (2015) Petrogenesis of late-Variscan high-K alkali-calcic granitoids and calc-alkalic lamprophyres: The AberIldut/North-Ouessant complex, Armorican Massif, France. Lithos 238: 140-155

Castro A, Patiño-Douce AE, Corretgé LG, de la Rosa JD, El-Biad M, El-Hmidi H (1999) Origin of peraluminous granites and granodiorites, Iberian massif, Spain: an experimental test of granite petrogenesis. Contrib Mineral Petrol 135: 255-276

Cathelineau M (1982) Les gisements d'uranium liés spatialement aux leucogranites sud armoricains et à leur encaissant métamorphique: relations et interactions entre les 
minéralisations et divers contextes géologiques et structuraux. Sciences de la Terre, Mémoires 42. Université de Nancy.

713

714

Cathelineau M (1981) Les Gisements Uraniferes de la Presqu'ile Guerandaise (Sud Bretagne); Approche Structurale et Metallogenique. Miner Deposita 16: 227-240

Cathelineau M, Boiron MC, Holliger P, Poty B (1990) Metallogenesis of the French part of the Variscan orogen. Part II: Time-space relationships between U, Au and Sn-W ore deposition and geodynamic events - mineralogical and U-Pb data. Tectonophysics 177: 59-79

Černý P, Ercit TS (2005) The Classification of Granitic Pegmatites Revisited. Can Mineral 43: 2005-2026

Cháb J, Stráník Z, Eliáš M (2007) Geologická mapa České republiky 1: 500 000. Česká geologická služba, Praha, Czech Republic

Chantraine J, Autran J, Cavelier C (2003) Carte géologique de la France 1: 1000 000, 6ème édition révisée. BRGM

Chelle-Michou C, Laurent O, Moyen JF, Block S, Paquette JL, Couzinié S, Gardien V, Vanderhaeghe O, Villaros A, Zeh A (2017) Pre-Cadomian to late-Variscan odyssey of the eastern Massif Central, France: formation of the West European crust in a nutshell. Gondwana Res 46: 170-190

Civis Llovera J (2015) Mapas geológicos de España y Portugal 1:1 000 000. IGME: Instituto Geológico y Minero de España

Clifford TN, Barton ES, Stern RA, Duchesne JC (2004) U-Pb Zircon Calendar for Namaquan (Grenville) Crustal Events in the Granulite-facies Terrane of the O'okiep Copper District of South Africa. J Petrol 45: 669-691 
Cuney M (2010) Evolution of uranium fractionation processes through time: driving the secular variation of uranium deposit types. Econ Geol 105: 553-569

Cuney M, Barbey P (2014) Uranium, rare metals, and granulite-facies metamorphism. Geosci Front 5: 729-745

Cuney M, Kyser T K (2008) Recent and not-so-recent developments in uranium deposits and implications for exploration. Mineralogical Association of Canada, Short Course Series 39

740

Cuney M, Friedrich M, Blumenfeld P, Bourguignon A, Boiron MC, Vigneresse JL, Poty B (1990) Metallogenesis in the French part of the Variscan orogen. Part I: U preconcentrations in pre-Variscan and Variscan formations - a comparison with Sn, W and Au. Tectonophysics 177: $39-57$

Dabard MP, Peucat JJ (2001) Les métasédiments de Bretagne sud. Rapport BRGM

Dabard MP (1997) Les Formations à cherts carbonés (phtanites) de la chaîne cadomienne; genèse et signification géodynamique; exemple du segment Armoricain. Documents du BRGM 267

Dabard MP, Loi A, Peucat JJ (1996) Zircon typology combined with Sm-Nd whole-rock isotope analysis to study Brioverian sediments from the Armorican Massif. Sediment Geol 101: $243-260$

Duchesne JC, Auwera JV, Liégeois JP, Barton ES, Clifford TN (2007) Geochemical constraints of the petrogenesis of the O'okiep Koperberg Suite and granitic plutons in Namaqualand, South Africa: A crustal source in Namaquan (Grenville) times. Precambrian Res 153: 116-142 
Ducassou C, Poujol M, Ruffet G, Bruguier O, Ballèvre M (2014) Relief variation and erosion of the Variscan belt: detrital geochronology of the Palaeozoic sediments from the Mauges Unit (Armorican Massif, France). Geol Soc Lond Spec Publ 405: 137-167

Eglinger A, Vanderhaeghe O, André-Mayer AS, Goncalves P, Zeh A, Durand C, Deloule E (2016) Tectono-metamorphic evolution of the internal zone of the Pan-African Lufilian orogenic belt (Zambia): Implications for crustal reworking and syn-orogenic uranium mineralizations. Lithos 240-243: 167-188

Euzen T (1993) Pétrogenèse des granites de collision post-épaississement. Le cas des granites crustaux et mantelliques du complexe de Pontivy-Rostrenen (Massif Armoricain, France). Mémoires Géosciences Rennes 51

Fusán O, Kodym O, Matějka A et al. (1967) Geological map of Czechoslovakia 1:500 000. Czech Geological Survey, Praha

Gao P, Zheng Y, Zhao Z (2016) Experimental melts from crustal rocks: A lithochemical constraint on granite petrogenesis. Lithos 266: 133-157

Gapais D, Brun JP, Gumiaux C, Cagnard F, Ruffet G, Le Carlier De Veslud C (2015) Extensional tectonics in the Hercynian Armorican belt (France). An overview. B Soc Geol Fr 186: $117-129$

García-Arias M, Corretgé LG, Fernández C, Castro A (2015) Water-present melting in the middle crust: The case of the Ollo de Sapo gneiss in the Iberian Massif (Spain). Chem Geol 419: 176-191 
774 Gauthier-Lafaye F, Weber F (2003) Natural nuclear fission reactors: time constraints for 775 occurrence, and their relation to uranium and manganese deposits and to the evolution of the atmosphere. Precambrian Res 120: 81-100.

777

Geisler T, Vinx R, Martin-Gombojav N, Pidgeon RT (2005) Ion microprobe (SHRIMP) dating of detrital zircon grains from the quartzites of the Eckergneiss Complex, Harz Mountains (Germany): implications for the provenance and the geological history. Int J Earth Sci 94: 369384

Gerdes A, Zeh A (2009) Zircon formation versus zircon alteration - New insights from combined $\mathrm{U}-\mathrm{Pb}$ and $\mathrm{Lu}-\mathrm{Hf}$ in-situ LA-ICP-MS analyses, and consequences for the interpretation of Archean zircon from the Central Zone of the Limpopo Belt. Chem Geol 261: $230-243$

Gerdes A, Zeh A (2006) Combined U-Pb and Hf isotope LA-(MC-)ICP-MS analyses of detrital zircons: Comparison with SHRIMP and new constraints for the provenance and age of an Armorican metasediment in Central Germany. Earth Planet Sci Lett 249: 47-61

Georget Y (1986) Nature et origine des granites peralumineux à cordiérite et des roches associées. Exemples des granitoides du Massif Armoricain (France): Pétrologie et géochimie. Mémoires Géosciences Rennes 9

Gumiaux C, Judenherc S, Brun JP, Gapais D, Granet M, Poupinet G (2004b) Restoration of lithosphere-scale wrenching from integrated structural and tomographic data (Hercynian belt of western France). Geology 32: 333-336

Gumiaux C, Gapais D, Brun JP, Chantraine J, Ruffet G (2004a) Tectonic history of the Hercynian Armorican Shear belt (Brittany, France). Geodin Acta 17: 289-307 
Höhn S, Koglin N, Klopf L, Schüssler U, Tragelehn H, Frimmel HE, Zeh A, Brätz H (2017)

797 Geochronology, stratigraphy and geochemistry of Cambro-Ordovician, Silurian and Devonian

798

799

800

801

802

803

804

805

806

807

808

809

810

811

812

813

814

815

816

volcanic rocks of the Saxothuringian Zone in NE Bavaria (Germany) - new constraints for

Gondwana break up and ocean-island magmatism. Int J Earth Sci 1-19

Jolivet J, Bienfait G, Vigneresse JL, Cuney M (1989) Heat flow and heat production in Brittany

(Western France). Tectonophysics 159: 61-72

Jones KA, Brown M (1990) High-temperature "clockwise"P-T paths and melting in the development of regional migmatites: an example from southern Brittany, France. J Metamorph.

Geol 8: 551-578

Koglin N, Zeh A, Franz G, Schüssler U, Glodny J, Gerdes A, Brätz H (2018) From Cadomian magmatic arc to Rheic ocean closure: The geochronological-geochemical record of nappe protoliths of the Münchberg Massif, NE Bavaria (Germany). Gondwana Res 55: 135-152

Kretz R (1983) Symbols for rock-forming minerals. Am Mineral 68: 277-279

Kroner U, Romer RL (2013) Two plates - Many subduction zones: The Variscan orogeny reconsidered. Gondwana Res 24: 298-329

Laurent O, Couzinié S, Zeh A, Vanderhaeghe O, Moyen JF, Villaros A, Gardien V, ChelleMichou C (2017) Protracted, coeval crust and mantle melting during Variscan late-orogenic evolution: $\mathrm{U}-\mathrm{Pb}$ dating in the eastern French Massif Central. Int J Earth Sci 1-31

Le Fort P, Cuney M, Deniel C, France-Lanord C, Sheppard SMF, Upreti BN, Vidal P (1987) Deep Seated Processes in Collision Zones Crustal generation of the Himalayan leucogranites. Tectonophysics 134: 39-57 
Le Gall B, Authemayou C, Ehrhold A, Paquette JL, Bussien D, Chazot G, Aouizerat A, Pastol $\mathrm{Y}$ (2014) LiDAR offshore structural mapping and $\mathrm{U} / \mathrm{Pb}$ zircon/monazite dating of Variscan strain in the Leon metamorphic domain, NW Brittany. Tectonophysics 630: 236-250

Le Hébel F (2002) Déformation continentale et histoire des fluides au cours d'un cycle subduction, exhumation, extension. Exemple des porphyroïdes Sud-Armoricains. Dissertation, Université de Rennes 1

Linnemann U, Gerdes A, Hofmann M, Marko L (2014) The Cadomian Orogen: Neoproterozoic to Early Cambrian crustal growth and orogenic zoning along the periphery of the West African Craton - Constraints from U-Pb zircon ages and $\mathrm{Hf}$ isotopes (Schwarzburg Antiform, Germany). Precam Res 244: 236-278

Linnemann U, Pereira F, Jeffries TE, Drost K, Gerdes A (2008) The Cadomian Orogeny and the opening of the Rheic Ocean: the diacrony of geotectonic processes constrained by LA-ICPMS U-Pb zircon dating (Ossa-Morena and Saxo-Thuringian Zones, Iberian and Bohemian Massifs). Tectonophysics 461: 21-43

López-Moro FJ, López-Plaza M, Gutiérrez-Alonso G, Fernández-Suárez J, López-Carmona A, Hofmann M, Romer RL (2017) Crustal melting and recycling: geochronology and sources of Variscan syn-kinematic anatectic granitoids of the Tormes Dome (Central Iberian Zone). A UPb LA-ICP-MS study. Int J Earth Sci. https://doi.org/10.1007/s00531-017-1483-8

Marcoux E (1982) Etude géologique et métallogénique du district plombo-zincifère de Pontivy (Massif armoricain, France): Relations avec les paragenèses stannifères et uranifères. Bull $\operatorname{BRGM}(2)$, section II, $n^{\circ} 1: 1-24$

Marcoux E, Cocherie A, Ruffet G, Darboux JR, Guerrot C (2009) Géochronologie revisitée du dôme du Léon (Massif armoricain, France). Géologie Fr 1: 19-40 

metamorphic event in NW and Central Iberia: relationships to crustal thickening, extension, orocline development and crustal evolution. Geol Soc Lond Spec Publ 405:225-247

Matteini M, Pavanetto P, Dabard MP, Hauser N, Loi A, Funedda A (2014) U-Pb ages and Hf isotopes on detrital zircons from Neoproterozoic sediments from the Armorican Massif (NW France): western Gondwana as possible source. 9th South American Symposium on Isotope Geology (SSAGI). 6-9 April 2014, Sao Paulo (Brazil)

Michard A, Gurriet P, Soudant M, Albarede F (1985) Nd isotopes in French Phanerozoic shales: external vs. internal aspects of crustal evolution. Geochim Cosmochim Acta 49: 601-610

Montel JM, Vielzeuf D (1997) Partial melting of metagreywackes, Part II. Compositions of minerals and melts. Contrib Mineral Petrol 128: 176-196

Montel JM (1993) Geochemistry of Accessory Minerals A model for monazite/melt equilibrium and application to the generation of granitic magmas. Chem Geol 110: 127-146.

Nance DR, Murphy BJ (1994) Contrasting basement isotopic signatures and the palinspastic restoration of peripheral orogens: An example from the Neoproterozoic Avalonian-Cadomian belt. Geology 22: 617-620

Patiño-Douce AE (1999) What do experiments tell us about the relative contributions of crust and mantle to the origin of granitic magmas? Geol Soc Lond Spec Publ 168: 55-75.

Patiño-Douce AE and Johnston AD (1991) Phase equilibria and melt productivity in the pelitic system: implications for the origin of peraluminous granitoids and aluminous granulites. Contrib. Mineral Petrol 107: 202-218 
862

863

864

865

866

867

868

869

870

871

872

873

874

875

876

877

878

879

880

881

882

Peiffert C, nguyen-Trung C, Cuney M (1996) Uranium in granitic magmas: Part 2. Experimental determination of uranium solubility and fluid-melt partition coefficients in the uranium oxide-haplogranite- $\mathrm{H}_{2} \mathrm{O}-\mathrm{NaX}(\mathrm{X}=\mathrm{Cl}, \mathrm{F})$ system at $770^{\circ} \mathrm{C}, 2$ kbar. Geochim Cosmochim Acta 60: 1515-1529

Peiffert C, Cuney M, Nguyen-Trung C (1994) Uranium in granitic magmas: Part 1. Experimental determination of uranium solubility and fluid-melt partition coefficients in the uranium oxide-haplogranite- $\mathrm{H}_{2} \mathrm{O}-\mathrm{Na}_{2} \mathrm{CO}_{3}$ system at $720-770^{\circ} \mathrm{C}, 2 \mathrm{kbar}$. Geochim Cosmochim Acta 58: 2495-2507.

Pelhate A (1994) Carboniferous of the Armorican Massif. In: Chantraine J, Rolet J, Santallier DS, Piqué A, Keppie JD (eds) Pre-Mesozoic Geology in France and Related Areas. Springer, Berlin, Heidelberg, pp 162-168

Pochon A, Poujol M, Gloaguen E, Branquet Y, Cagnard F, Gumiaux C, Gapais D (2016). U$\mathrm{Pb}$ LA-ICP-MS dating of apatite in mafic rocks: Evidence for a major magmatic event at the Devonian-Carboniferous boundary in the Armorican Massif (France). Am Mineral 101: 24302442

Peucat JJ, Auvray B, Hirbec Y, Calvez JY (1984) Granites et cisaillements hercyniens dans le Nord du Massif Armoricain; geochronologie Rb-Sr. Bull. B Soc Geol Fr S7-XXVI: 1365-1373

Raith JG (1995) Petrogenesis of the Concordia Granite Gneiss and its relation to W-Mo mineralization in western Namaqualand, South Africa. Precambrian Res 70: 303-335

Robb LJ (1986) Uraniferous leucogranites from the Namaqualand Metamorphic Complex: Part I-Geology, geochemistry and petrogenesis. Mineral Deposits of Southern Africa 2: 1609-1627 
Robb LJ, Armstrong RA, Waters DJ (1999) The History of Granulite-Facies Metamorphism and Crustal Growth from Single Zircon U-Pb Geochronology: Namaqualand, South Africa. J Petrol 40: 1747-1770

Romer RL, Kroner U (2016) Phanerozoic tin and tungsten mineralization-Tectonic controls on the distribution of enriched protoliths and heat sources for crustal melting. Gondwana Res 31: $60-95$

Romer RL, Kroner U (2015). Sediment and weathering control on the distribution of Paleozoic magmatic tin-tungsten mineralization. Miner Deposita 50: 327-338

Romer RL, Schneider J, Linnemann U (2010) Post-Variscan deformation and hydrothermal mineralization in Saxo-Thuringia and beyond: a geochronologic review in Linnemann U, Romer RL (eds) Pre-Mesozoic Geology of Saxo-Thuringia - From the Cadomian Active Margin to the Variscan Orogen, Schweizerbart, Stuttgart, pp 347-360

Romer RL, Thomas R, Stein HJ, Rhede D (2007) Dating multiply overprinted Sn-mineralized granites - examples from the Erzgebirge, Germany. Miner Deposita 42: 337-359

Rudnick RL, Gao S (2003) Composition of the continental crust. Treatise on geochemistry 3

Samson SD, D'lemos RS (1998) U-Pb geochronology and Sm-Nd isotopic composition of Proterozoic gneisses, Channel Islands, UK. J Geol Soc 155: 609-618

Scherer E, Münker C, Mezger K (2001) Calibration of the Lutetium-Hafnium Clock. Science 293: 683-687

Söderlund U, Patchett PJ, Vervoort JD, Isachsen CE (2004) The ${ }^{176} \mathrm{Lu}$ decay constant determined by $\mathrm{Lu}-\mathrm{Hf}$ and $\mathrm{U}-\mathrm{Pb}$ isotope systematics of Precambrian mafic intrusions. Earth Planet Sci Lett 219: 311-324 
Petrogenesis of rare-metal pegmatites in high-grade metamorphic terranes: A case study from the Lewisian Gneiss Complex of north-west Scotland. Precambrian Res 281: 338-62

Tartèse R, Boulvais P (2010) Differentiation of peraluminous leucogranites "en route" to the surface. Lithos 114: 353-368

Tartèse R, Boulvais P, Poujol M, Gloaguen E, Cuney M (2013) Uranium Mobilization from the Variscan Questembert Syntectonic Granite During Fluid-Rock Interaction at Depth. Econ Geol 108: $379-386$.

Tartèse R, Boulvais P, Poujol M, Chevalier T, Paquette JL, Ireland TR, Deloule E (2012) Mylonites of the South Armorican Shear Zone: Insights for crustal-scale fluid flow and waterrock interaction processes. J Geodyn 56-57: 86-107

Tartèse R, Ruffet G, Poujol M, Boulvais P, Ireland TR (2011b) Simultaneous resetting of the muscovite K-Ar and monazite U-Pb geochronometers: a story of fluids. Terra Nova 23: 390398

Tartèse R, Poujol M, Ruffet G, Boulvais P, Yamato P, Košler J (2011a) New U-Pb zircon and ${ }^{40} \mathrm{Ar} /{ }^{39} \mathrm{Ar}$ muscovite age constraints on the emplacement of the Lizio syn-tectonic granite (Armorican Massif, France). Comptes Rendus Geosci 343: 443-453

Taylor SR, McLennan SM (1985) The continental crust: Its composition and evolution

Thiéblemont D, Cataing C, Billa M, Bouton P, Préat (2009) Notice explicative de la Carte géologique et des Ressources minérales de la République Gabonaise à 1: 1000 000. Editions DGMG - Ministère des Mines, du Pétrole, des Hydrocarbures, Libreville 
926

927

928

929

930

931

932

933

934

935

936

937

938

939

940

941

942

943

944

945

946

947

Thomas RJ, De Beer CH, Bowring SA (1996) A comparative study of the Mesoproterozoic late orogenic porphyritic granitoids of southwest Namaqualand and Natal, South Africa. J Afr Earth Sci 23: 485-508

Tichomirowa M, Sergeev S, Berger HJ, Leonhardt D (2012) Inferring protoliths of high-grade metamorphic gneisses of the Erzgebirge using zirconology, geochemistry and comparison with lower-grade rocks from Lusatia (Saxothuringia, Germany). Contrib Mineral Petrol 164: 375396

Tischendorf G, Förster HJ (1994) Hercynian granite magmatism and related metallogenesis in the Erzgebirge: A status report. Mineral deposits of the Erzgebirge/Krusne hory (Germany/Czech Republic). Monogr Ser Mineral Deposits 31: 5-23

Trautmann F, Carn, A (1997) La Guerche-De-Bretagne 354, Carte géologique de France 1:50 000. BRGM

Turpin L, Cuney M, Friedrich M, Bouchez JL, Aubertin M (1990) Meta-igneous origin of Hercynian peraluminous granites in N.W. French Massif Central: implications for crustal history reconstructions. Contrib Mineral Petrol 104: 163-172

Vermeesch P (2012) On the visualisation of detrital age distributions. Chem Geol 312: 190194

Vernhet Y, Plaine J, Trautmann F, Pivette B (2009) Cossé-Le-Vivien 355, Carte géologique de France 1:50 000. BRGM

Vidal M, Dabard MP, Gourvenec R, Le Hérissé A, Loi A, Paris F, Plusquellec Y, Racheboeuf PR (2011) Le Paléozoïque de la presqu'île de Crozon, Massif armoricain (France). Géologie de la France 1: 3-45 
Vidal P, Auvray B, Charlot R, Cogné J (1981). Precadomian relicts in the Armorican Massif:

Their age and role in the evolution of the western and central European Cadomian-Hercynian belt. Precambrian Res 14: 1-20

Vielzeuf D, Holloway JR (1988) Experimental determination of the fluid-absent melting relations in the pelitic system. Contrib Mineral Petrol 98: 257-276

Vigneresse JL, Cuney M, Jolivet J, Bienfait G (1989) Selective heat-producing element enrichment in a crustal segment of the mid-European Variscan chain. Tectonophysics 159: 4760

Villaseca C, Martínez EM, Orejana D, Andersen T, Belousova E (2016) Zircon Hf signatures from granitic orthogneisses of the Spanish central system: Significance and sources of the Cambro-Ordovician magmatism in the Iberian Variscan Belt. Gondwana Res 34: 60-83

Villaseca C, Orejana D, Belousova EA (2012) Recycled metaigneous crustal sources for S- and I-type Variscan granitoids from the Spanish Central System batholith: Constraints from Hf isotope zircon composition. Lithos 153: 84-93

Watson EB, Harrison TM (1983) Zircon saturation revisited: temperature and composition effects in a variety of crustal magma types. Earth Planet Sci Lett 64: 295-304

Wedepohl KH (2016) Chemical composition and fractionation of the continental crust. Geol Rundsch 80: 207-223

Zeh A, Gerdes A (2010) Baltica- and Gondwana-derived sediments in the Mid-German

Crystalline Rise (Central Europe): Implications for the closure of the Rheic ocean.

Gondwana Res 17: 254-263

Zeh A, Brätz H, Millar I L, Williams IS (2001) A combined zircon SHRIMP and Sm- 
970 Nd isotope study on high-grade paragneisses from the Mid-German Crystalline Rise:

971 Evidence for northern Gondwanan and Grenvillian provenance. J Geol Soc London,

972 158: 983-994 


\section{Captions}

974

975

976

977

978

979

980

981

982

983

984

985

986

987

988

989

990

991

992

993

994

995

996

997

Fig.1: Schematic representation of the west European Variscan belt representing the main terranes (Ballèvre et al. 2009, 2014; Ballèvre 2016) and showing the distribution of U deposits (Cuney and Kyser 2008), Variscan granitoids and Early Paleozoic felsic to intermediate igneous rocks (after the 1:1 000 000 geological maps of France [Chantraine et al. 2003], Portugal and Spain [Civis Llovera (2015)] and the 1:500 000 geological maps of Czechoslovakia [Fusán et al. 1967] and Czech Republic [Cháb et al. 2007]. The granitoids typology is from Barbarin (1999). MPG: muscovite-bearing peraluminous granites; CPG: cordierite-bearing peraluminous granitoids; KCG: K-rich and K-feldspar porphyritic calc-alkaline granitoids. ACG: amphibole-rich calc-alkaline granitoids. NASZ: North Armorican shear zone; NBSASZ: northern branch of the south Armorican shear zone; SBSASZ: southern branch of the south Armorican shear zone. NEF: Nort-sur-Erdre fault. Mineral abbreviations according to Kretz (1983).

Fig. 2: (a) principal structural domains from the Armorican Massif. (b) General geological map of the Armorican Massif [modified from Chantraine et al. (2003), Gapais et al. (2015) and Ballouard et al. (2017b, in press)] identifying the different types of Carboniferous granitoids after Barbarin (1999) and Capdevila (2010) and localizing the U deposits (http://infoterre.brgm.fr). The high heat production and flow belt (HHPFB) from Vigneresse et al. (1989) and Jolivet et al. (1989) is indicated. Locality numbers are referenced in Table 1. NASZ: north Armorican shear zone; NBSASZ: northern branch of the South Armorican shear zone; SBSASZ: southern branch of the south Armorican shear zone. Fe-K granites: ferro-potassic granites. Mg-K granites: magneso-potassic granites. Mineral abbreviations according to Kretz (1983).

Fig. 3: $\mathrm{A} / \mathrm{NK}\left[\mathrm{Al}_{2} \mathrm{O}_{3} /\left(\mathrm{Na}_{2} \mathrm{O}+\mathrm{K}_{2} \mathrm{O}\right)\right]$ versus $\mathrm{A} / \mathrm{CNK}\left[\mathrm{Al}_{2} \mathrm{O}_{3} /\left(\mathrm{CaO}+\mathrm{Na}_{2} \mathrm{O}+\mathrm{K}_{2} \mathrm{O}\right)\right]$ diagram (molar proportion) reporting the composition of Late Carboniferous MPGs from the Armorican Massif. Data 
are from Ballouard et al. (2015a, 2017a), Euzen (1993), Georget (1986), Tartèse and Boulvais (2010), Tartèse et al. (2012) and this study.

Fig. 4: U versus Th diagram reporting the whole-rock composition of Late Carboniferous MPGs from the Armorican Massif and their potential sources. Data are from this study, Georget (1986), Vigneresse et al. (1989), Euzen (1993), Béchennec et al. (1996, 1999, 2001), Trautmann and Carn (1997), Dabard and Peucat (2001), Le Hébel (2002), Tartèse and Boulvais (2010), Béchennec and Thiéblement (2013), Tartèse et al. (2012) and Ballouard et al. (2015a, 2017b). The average U content (2.7 ppm) and Th/U value ( 4) of the upper continental crust (UCC; Rudnick and Gao 2003) are indicated.

Fig. 5: Initial $\mathrm{Sr}$ and $\mathrm{Nd}$ isotopic composition calculated at $315 \mathrm{Ma}$ of Late Carboniferous MPGs from the Armorican Massif (Data from this study; Ballouard et al. 2015a, 2017b; Tartèse and Boulvais 2010). The yellow double arrow represents the $\varepsilon N d(315 \mathrm{Ma})$ composition of the Langonnet MPG (Ballouard et al. 2017b) whereas other vertical bars represent the $\varepsilon N d(315 \mathrm{Ma})$ composition of Cambro-Ordovician peraluminous igneous rocks [acid (meta)volcanics: Ballèvre et al. 2012; (meta)granitoids: Ballouard et al. 2017b] as well as Brioverian (Dabard et al. 1996; Dabard 1997) and Paleozoic (Michard et al. 1985; Dabard and Peucat 2001; this study) sediments. The composition of ca. 2000 Ma Icartian orthogneisses from the Channel Islands (black arrow) is out of the diagram with $\varepsilon \mathrm{Nd}(315 \mathrm{Ma})$ values between -18 and -14 (Samson and D’Lemos 1998). The grey dashed arrow represents the north-south evolution of the MPG isotopic composition. Sm-Nd isotopic composition of CHUR from Bouvier et al. (2008).

Fig. 6: Representative cathodoluminescence pictures of zircon grains from MPGs, sediments and Cambro-Ordovician metagranitoids of the Armorican Massif analyzed during this study. Dashed circles represent the location of LA-ICP-MS U-Pb analyses. The corresponding U-Pb dates ( $1 \sigma$ uncertainty) and $\operatorname{EHf}(\mathrm{t})$ values are indicated. All zircon grains are shown at the same scale and the scale bar is indicated in the upper right corner. Carbon. $=$ Carboniferous. 
1025 Figure 7: Histogram and Kernel density estimates (KDE) of U-Pb dates obtained on inherited zircon grains from Late Carboniferous MPGs of the Armorican Massif. Number in grey inside the diagrams corresponds to the age of peaks (Ma) obtained by KDE. Zones in color represent the main period of inheritance.

Fig. 8: Histogram and Kernel density estimates (KDE) of U-Pb dates obtained on detrital zircon grains from sedimentary rocks of the Armorican Massif. Zones in color represent the main period of inheritance recorded by zircon from the Late Carboniferous MPGs.

Fig. 9: Histogram and Kernel density estimates (KDE) of U-Pb dates obtained on zircon grains from Cambro-Ordovician and Early Carboniferous peraluminous igneous rocks of the Armorican Massif. Zones in color represent the main period of inheritance recorded by zircon from the Late Carboniferous MPGs.

Fig. 10: $\varepsilon H f(t)$ versus U-Pb ages for (a) inherited zircon grains from Late Carboniferous MPGs, (b) detrital zircon from sediments (c) magmatic zircon from Early Paleozoic metagranitoids and (d) zircon from Late Carboniferous MPGs and their potential sources. In (d), the composition of magmatic zircon from Early Variscan granitoids is extrapolated using Devonian-Carboniferous zircon from Lower Carboniferous sediments. The main origin of zircon grains is indicated: WA $=$ West African craton, $\mathrm{G}$ $=$ Grenvillian belt, $\mathrm{CA}=$ Cadomian-Avalonian belt, $\mathrm{R}=$ Cambro-Ordovician Rift, $\mathrm{EV}=$ Early Variscan. The crustal evolution trends are calculated using a ${ }^{176} \mathrm{Lu} /{ }^{177} \mathrm{Hf}$ ratio of 0.0113 (Taylor and McLennan 1985; Wedepohl 2016). Data for the Pontivy and Langonnet MPG are from Ballouard et al. (2017b) whereas other data are from this study. 
1049 Fig.11: U versus Th diagram reporting the whole-rock composition of granitoids from (a) the Archean 1050 Gabonese craton and (b) Mesoproterozoic western Namaqualand province, South Africa. 1051 Geochronological and Geochemical data for Gabon are from Bouton et al. (2009) and Thiéblemont et 1052 al. (2009) whereas data for Namaqualand are from Robb (1986, 1999), Raith (1995), Thomas et al. 1053 (1996), Clifford et al. (2004), Andreoli et al. (2006), Bailie et al. (2007) and Duchesne et al. (2007). The 1054 average $\mathrm{U}$ content (2.7 ppm) and Th/U value ( 4) of the upper continental crust (UCC; Rudnick and 1055 Gao 2003) are indicated.

1056

1057 Table 1: summary of zircon U-Pb data. Pop. = population. 


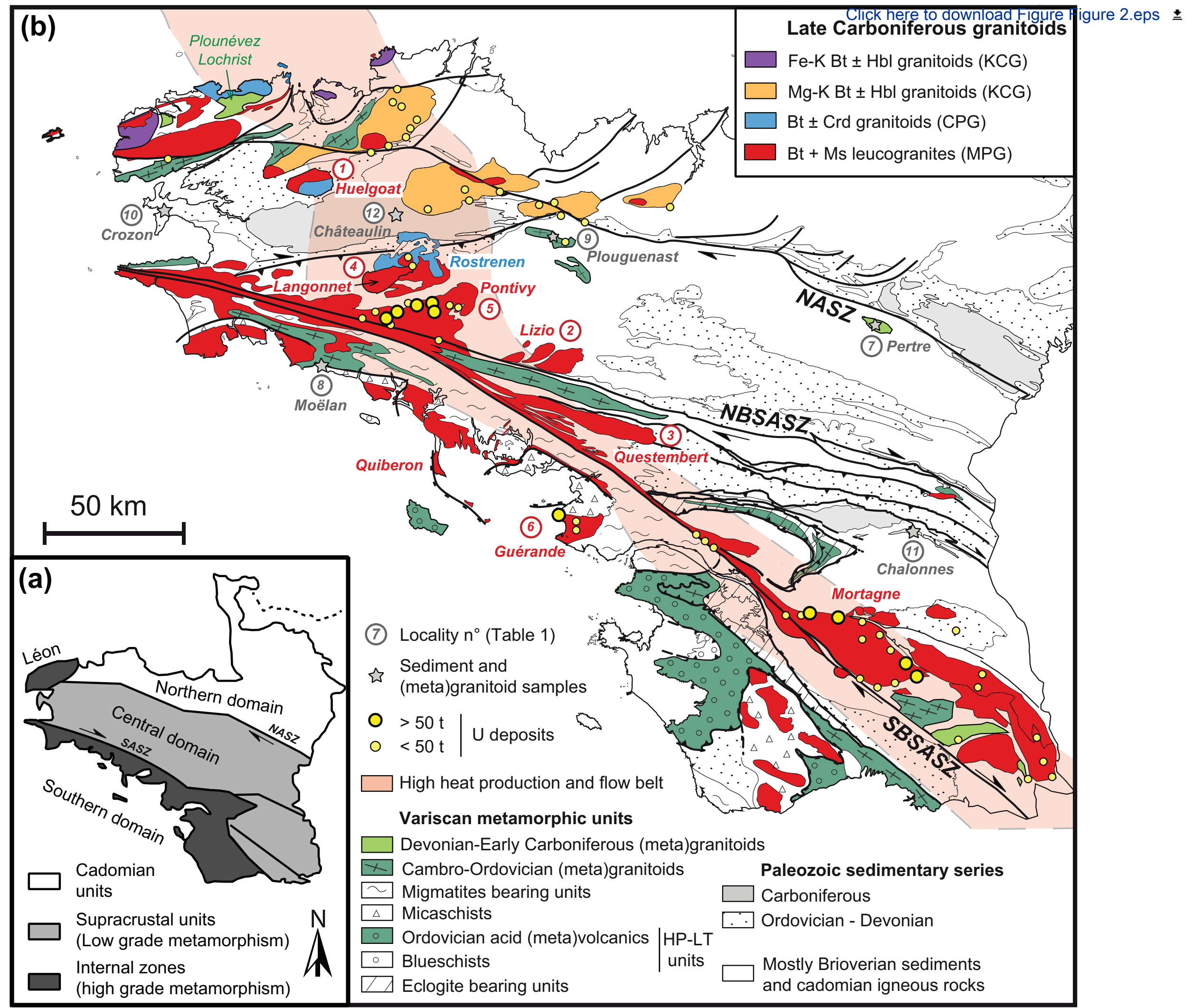




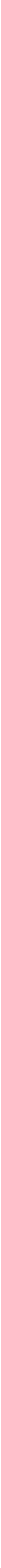


Figure 4 Late Carboniferous igneous rocks $\diamond$ MPGs

Early Carboniferous igneous rocks $\triangle$ Pertre MPG

Cambro-Ordovician peraluminous igneous rocks

$\square$ (Meta)volcanics

$\square$ (Meta)granitoids

Sediments

- Lower Carboniferous

- Ordovician-to-Devonian (central domain)

- Ordovician-to-Devonian (southern domain)

- Brioverian (central domain)

- Brioverian (southern domain)

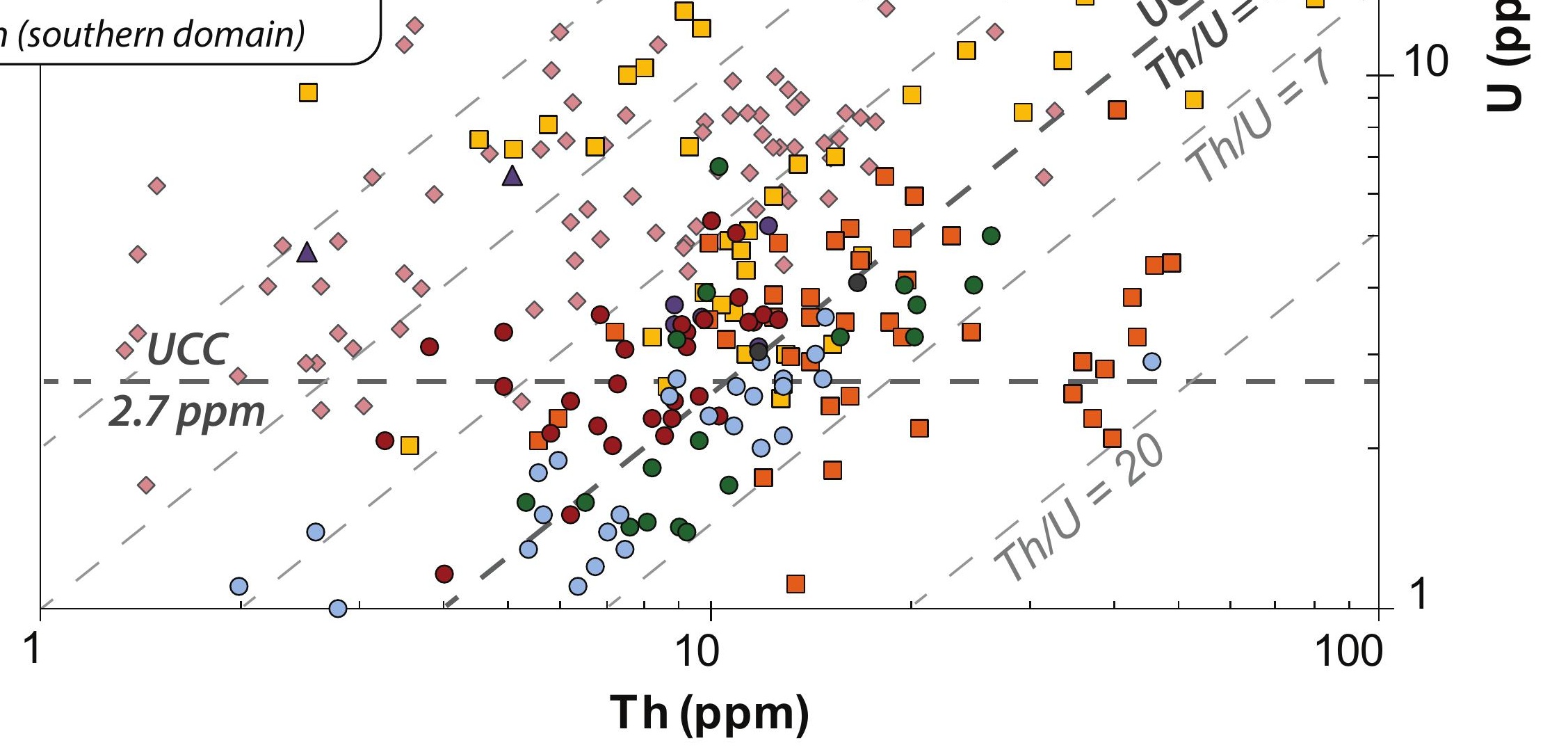




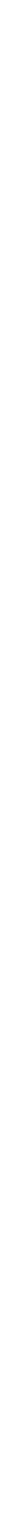




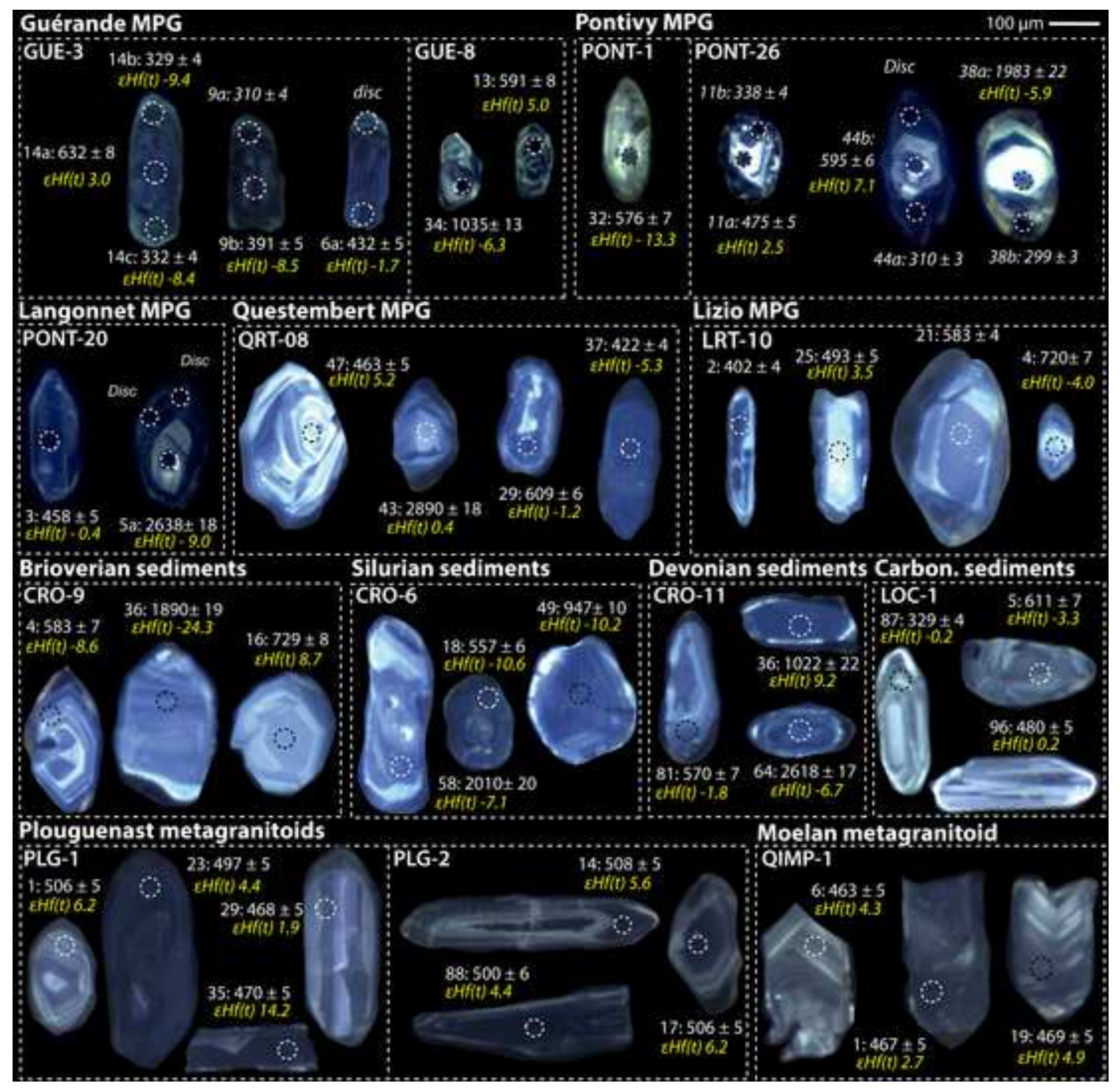



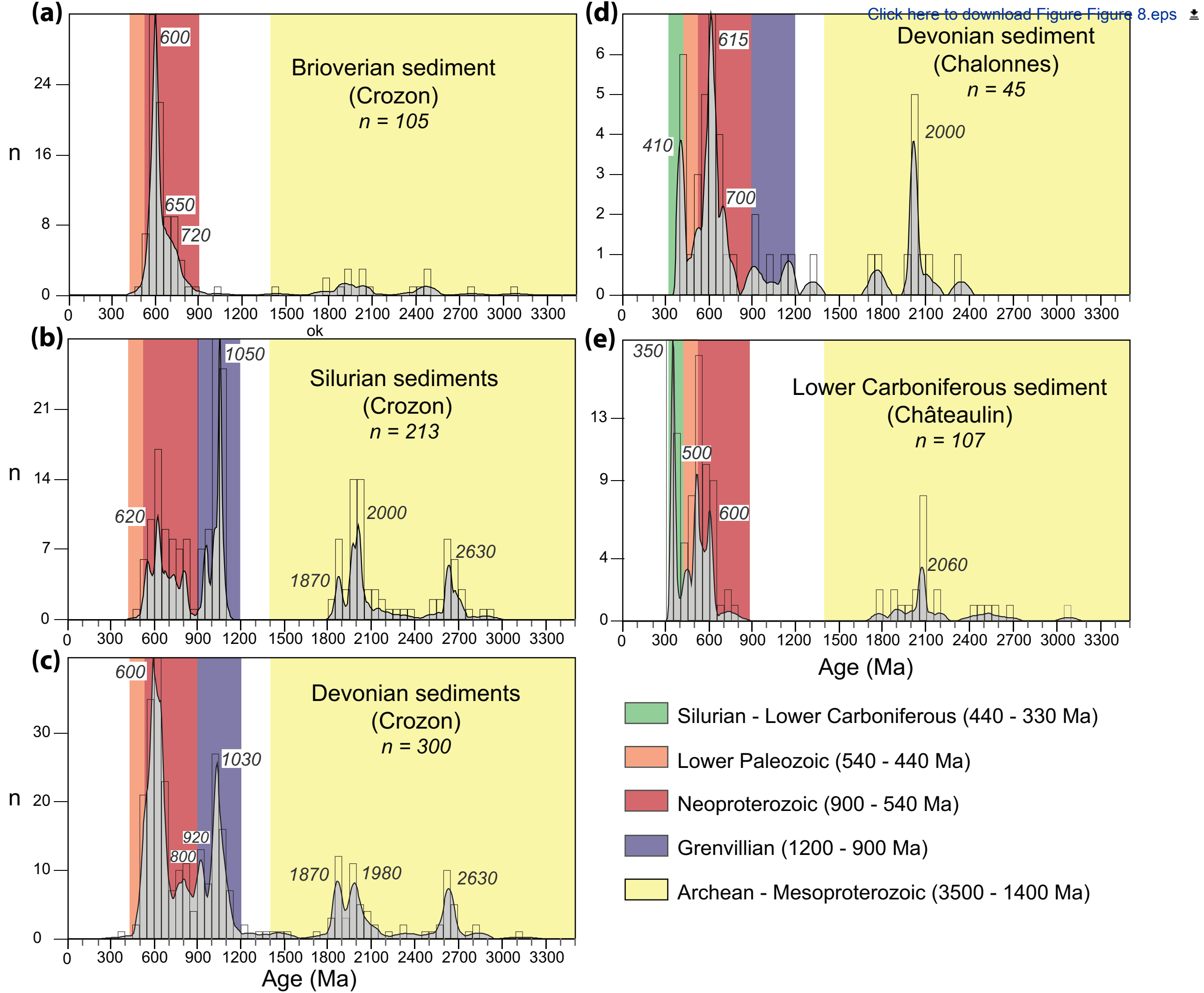
Age (Ma)

Silurian - Lower Carboniferous (440 - $330 \mathrm{Ma}$ )

Lower Paleozoic (540 - $440 \mathrm{Ma}$ )

Neoproterozoic (900 - $540 \mathrm{Ma}$ )

Grenvillian (1200 - $900 \mathrm{Ma}$ )

Archean - Mesoproterozoic (3500 - 1400 Ma)

Age (Ma) 

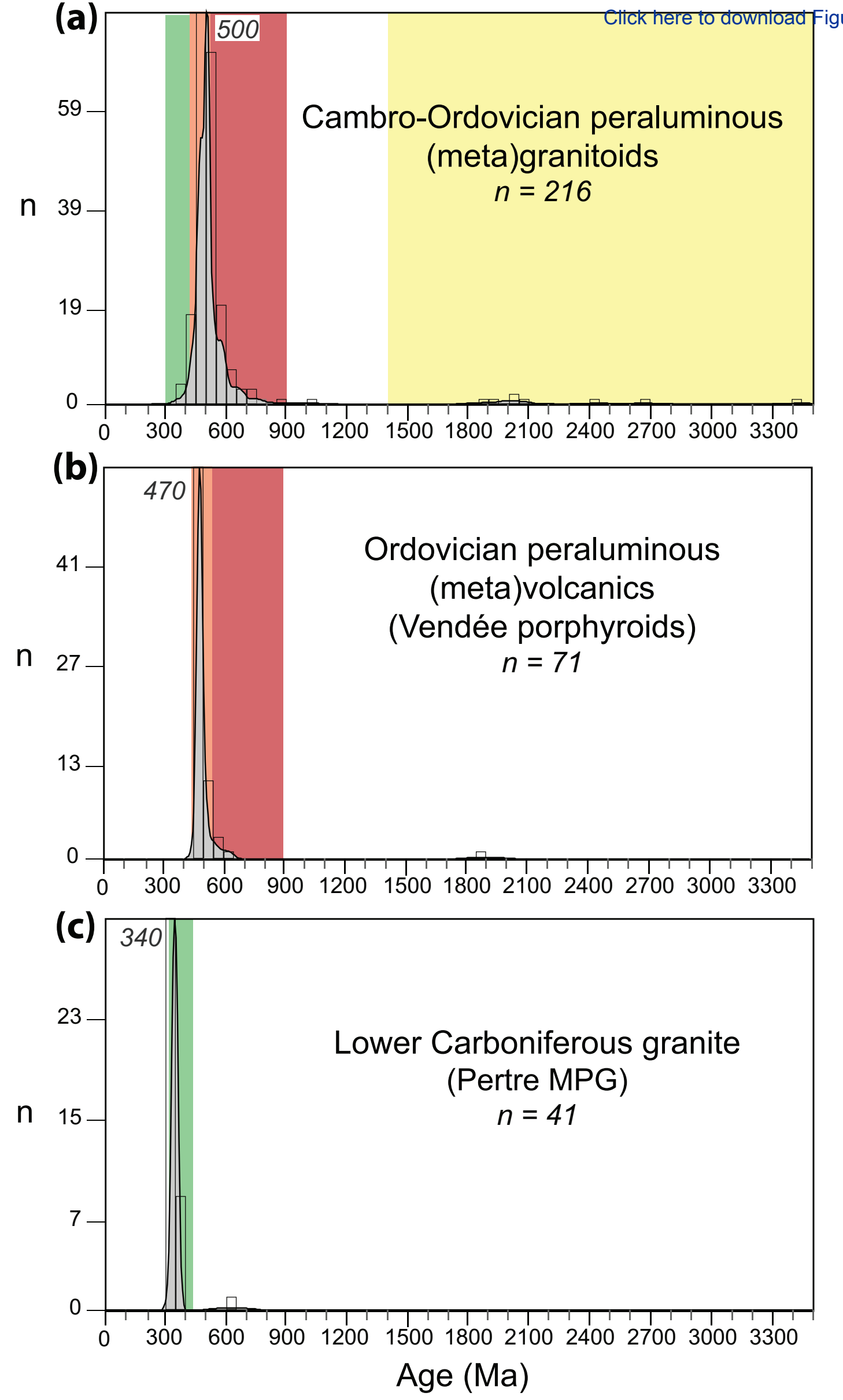

$\square$ Silurian - Lower Carboniferous (440 - $330 \mathrm{Ma}$ )

$\square$ Lower Paleozoic (540 - $440 \mathrm{Ma}$ )

Neoproterozoic (900 - $540 \mathrm{Ma}$ )

Archean - Mesoproterozoic (3500 - $1400 \mathrm{Ma})$ 

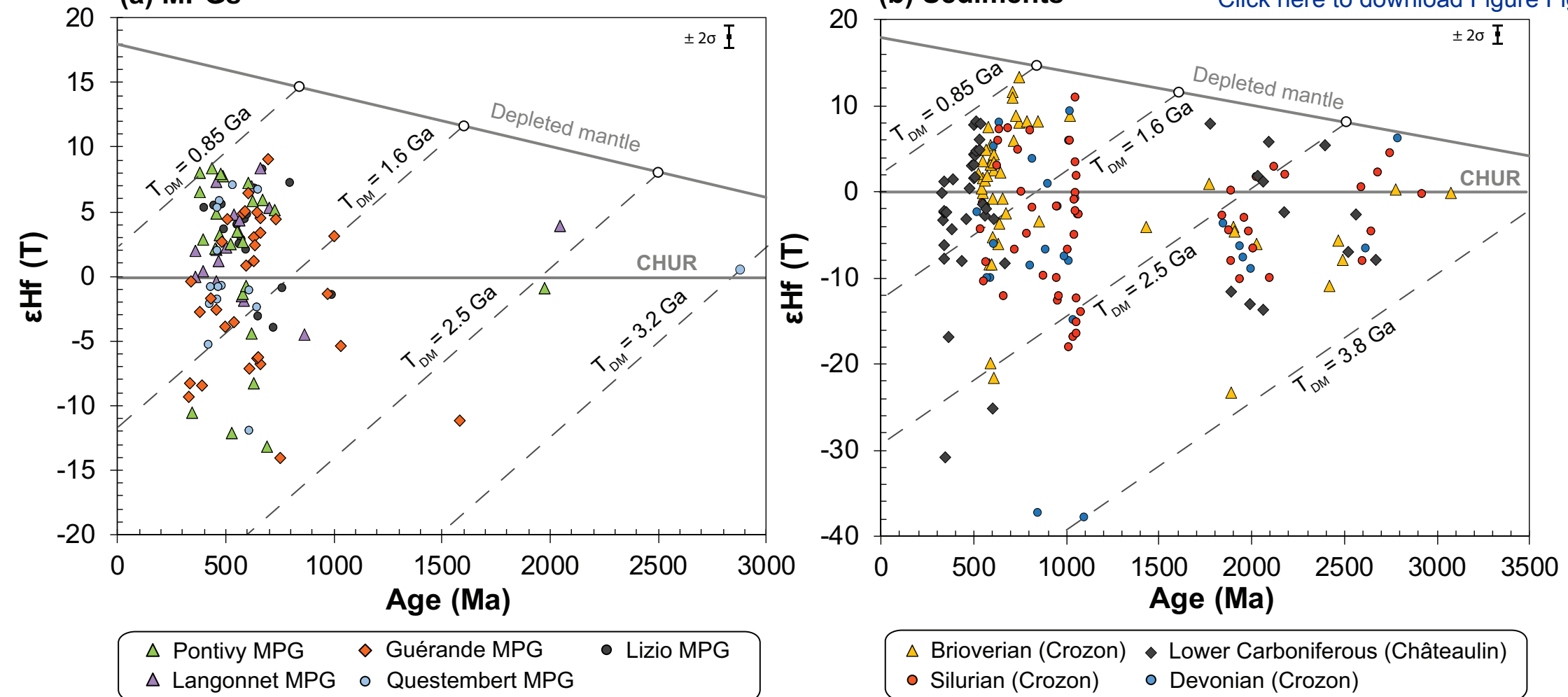

\section{(c) Cambro-Ordovician metagranitoids}

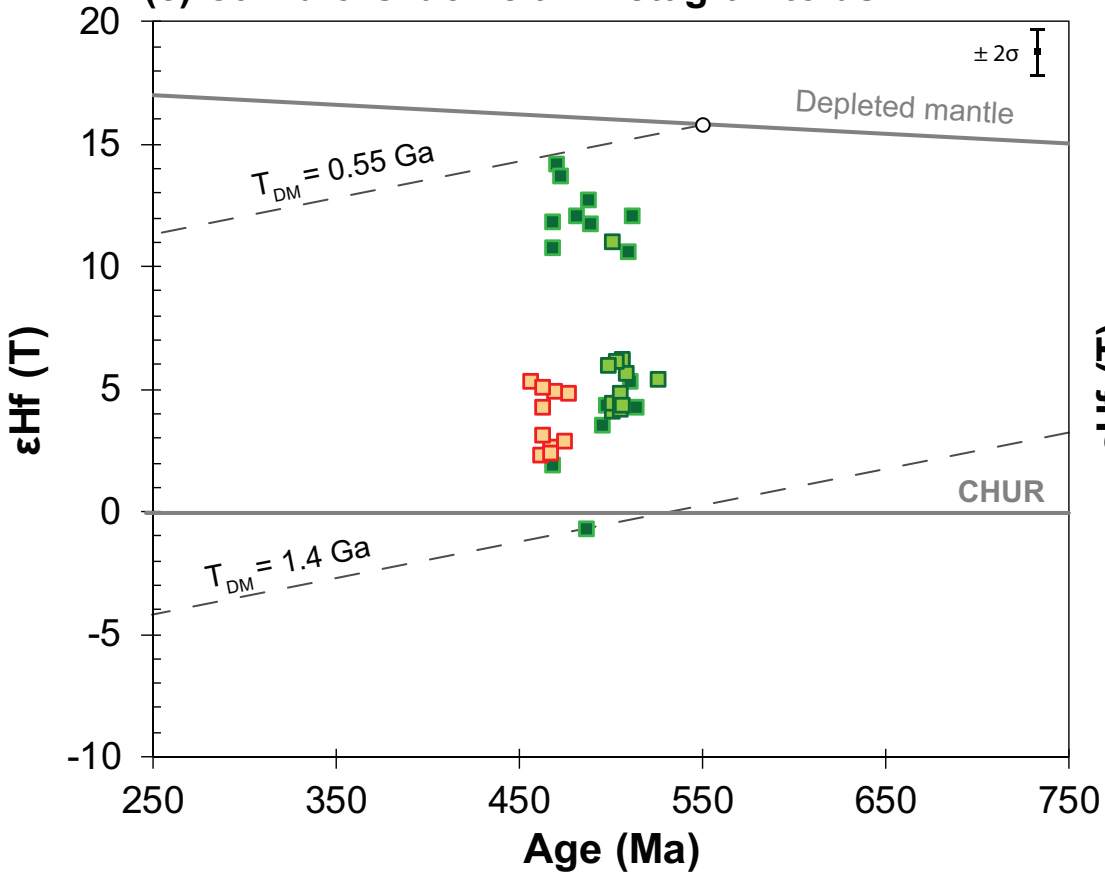

$\triangle$ Brioverian (Crozon) $\bullet$ Lower Carboniferous (Châteaulin)

- Silurian (Crozon)

- Devonian (Crozon)

\section{(d) MPGs and their potential sources}

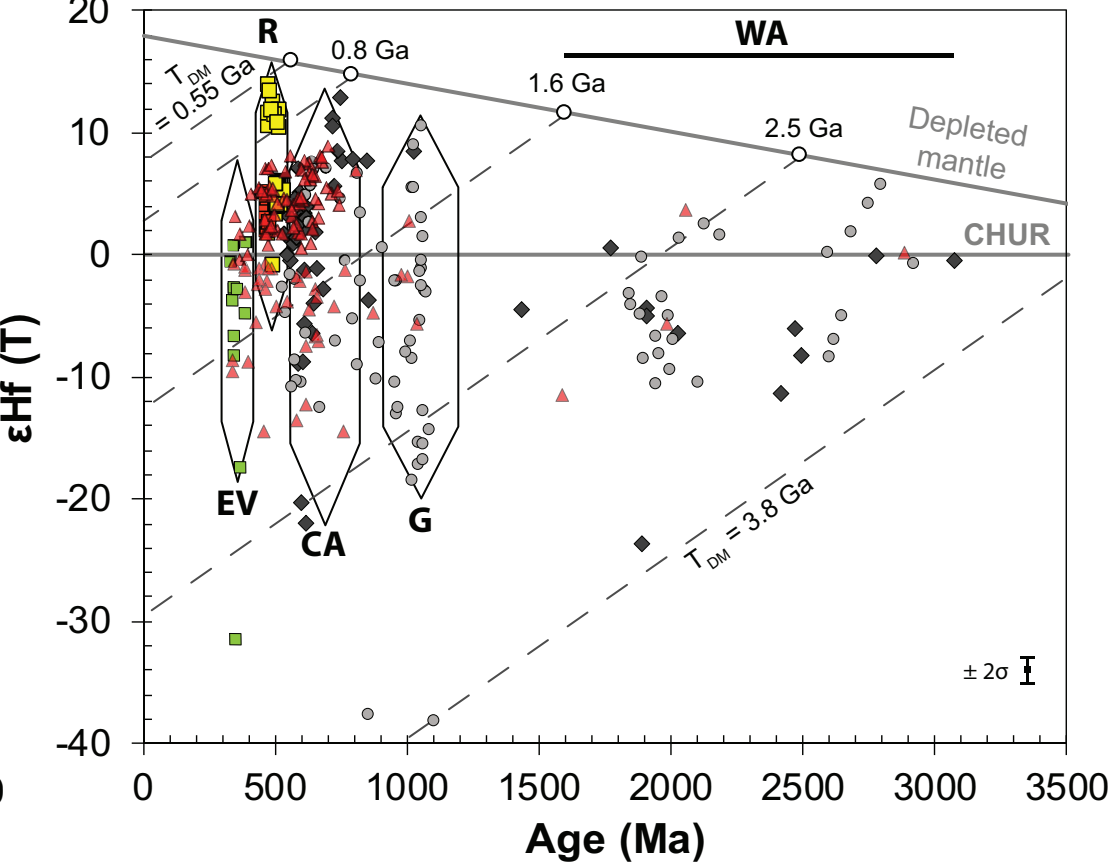

$\square$ Early Variscan granitoids (Lower Carboniferous sediments)

Lower Paleozoic metagranitoids

- Silurian and Devonian sediments

$\triangle$ All MPGs

- Brioverian sediment 
(a) Archean Gabonese craton

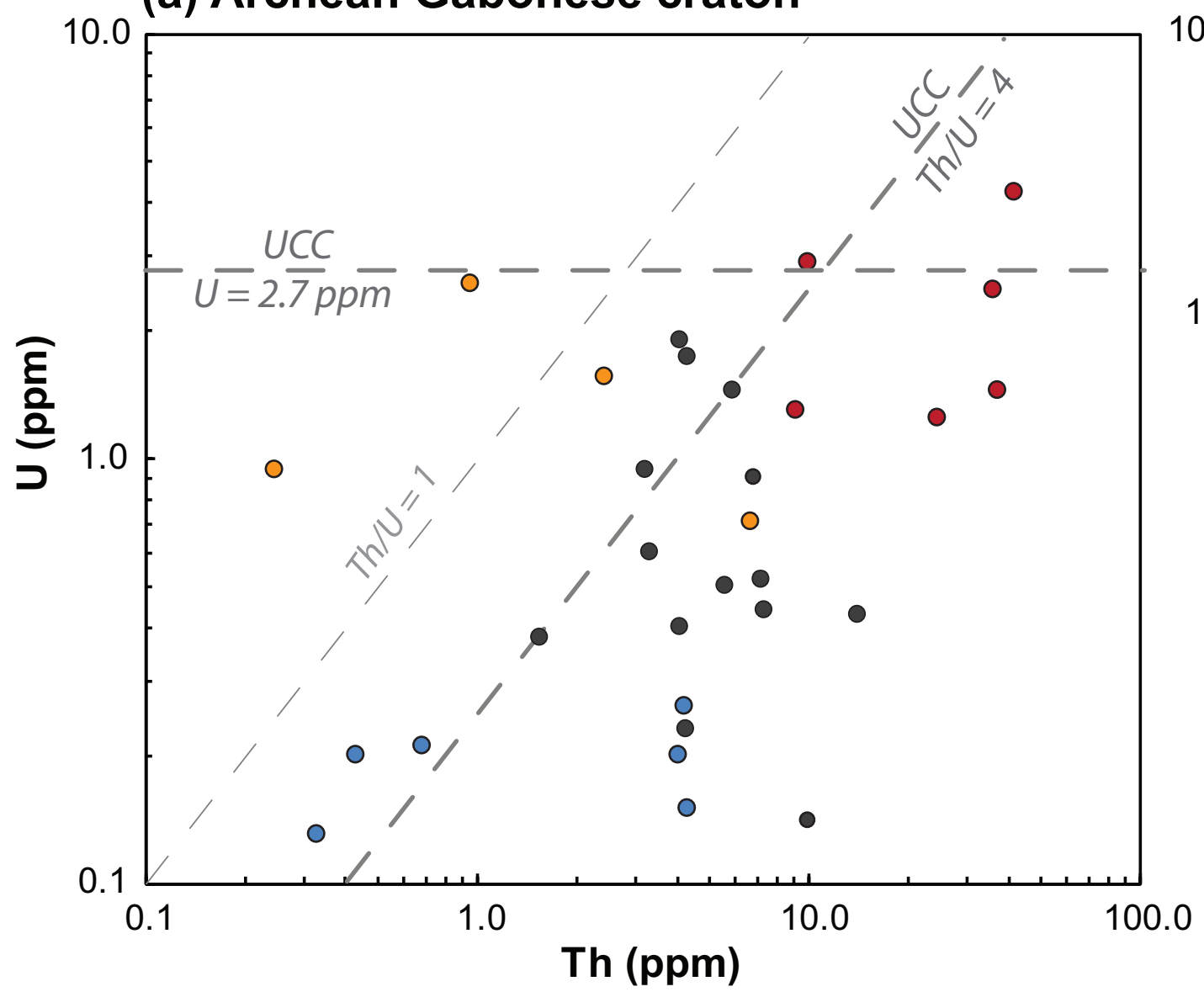

- Neoarchean granites and pegmatites ( 2.75 - $2.71 \mathrm{Ga})$

- Pink granites ( 2.88 - $2.81 \mathrm{Ga})$

- Grey granitoids ( 2.90 - $2.84 \mathrm{Ga})$

- TTG type Orthogneisses ( 2.94 - $2.87 \mathrm{Ga}$ ) (b) Mesoproterozoic Namaqualand province

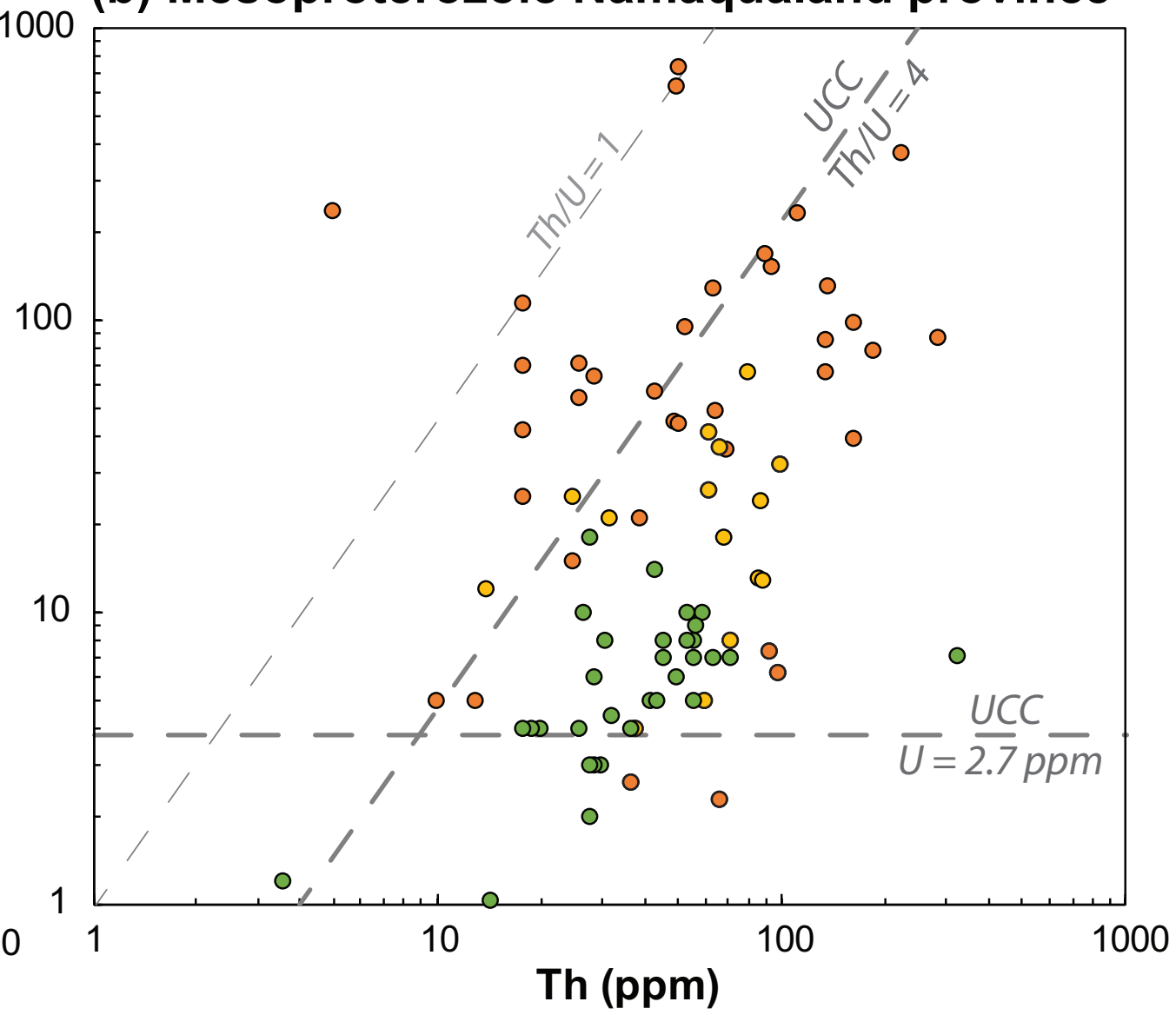

- Late Spektakel suite granites $(\sim 1.06-1.03 \mathrm{Ga})$

- Early Spektakel suite granites ( 1.06 Ga)

- Little Namaqualand suite granitic gneisses ( 1.2 Ga) 


\begin{tabular}{|c|c|c|c|c|c|c|c|c|c|c|c|}
\hline \multirow{2}{*}{ Reference } & \multirow[b]{2}{*}{ Sample } & \multirow{2}{*}{$\begin{array}{c}\text { Locality / intrusion } \\
\text { name }\end{array}$} & \multirow{2}{*}{$\begin{array}{l}\text { Reference } \mathbf{N}^{\circ} \text { in } \\
\text { Figure } 2\end{array}$} & \multirow[b]{2}{*}{ Rock type } & \multirow{2}{*}{ Intrusion / deposition age } & \multirow{2}{*}{$\begin{array}{l}\text { Number } \\
\text { U-Pb / Hf }\end{array}$} & \multirow{2}{*}{$\begin{array}{c}\text { Pop. 1 } \\
(\%) \\
3500- \\
1400 \mathrm{Ma}\end{array}$} & \multirow{2}{*}{$\begin{array}{c}\text { Pop. } 2 \\
(\%)\end{array}$} & \multirow{2}{*}{\begin{tabular}{|c|}
$\begin{array}{c}\text { Pop. 3 } \\
(\%)\end{array}$ \\
$\begin{array}{c}900-540 \\
\text { Ma }\end{array}$ \\
\end{tabular}} & \multirow{2}{*}{\begin{tabular}{|c|}
$\begin{array}{c}\text { Pop. } 4 \\
(\%)\end{array}$ \\
$\begin{array}{c}540-440 \\
\text { Ma }\end{array}$ \\
\end{tabular}} & \multirow{2}{*}{$\begin{array}{c}\begin{array}{c}\text { Pop. } 5 \\
(\%)\end{array} \\
440-330 \\
\mathrm{Ma}\end{array}$} \\
\hline & & & & & & & & & & & \\
\hline This study & LOC-1 & Châteaulin basin & 12 & Sandstone & Lower Carboniferous & $107 / 45$ & 22 & 0 & 23 & 22 & 32 \\
\hline Ducassou et al. (2014) & DevSA2 & Chalonnes & 11 & Sandstone & Devonian & $45 / 0$ & 24 & 11 & 42 & 7 & 13 \\
\hline This study & $\begin{array}{l}\text { CRO-6 } \\
\text { CRO-3 }\end{array}$ & Crozon & 10 & $\begin{array}{c}\text { Sandstone } \\
\text { Sandstone-siltstone }\end{array}$ & Silurian & $213 / 54$ & 36 & 32 & 29 & 3 & 0 \\
\hline This study & CRO-9 & Crozon & 10 & Sandstone & Brioverian & $105 / 48$ & 17 & 1 & 78 & 4 & 0 \\
\hline This study & $\begin{array}{l}\text { PLG-1 } \\
\text { PLG-2 } \\
\text { PLG-3 } \\
\text { PLG-4 } \\
\text { QIMP-1 }\end{array}$ & $\begin{array}{c}\text { Plouguenast } \\
\text { Moëlan }\end{array}$ & 9 & $\begin{array}{c}\text { Metagranitoid (MPG) } \\
\text { Metagranitoid (tonalite) } \\
\text { MPG } \\
\text { Metagranitoid (tonalite) } \\
\text { Metagranitoid (tonalite) }\end{array}$ & $\begin{array}{c}\text { Ordovician }(477.9 \pm 2.9 \mathrm{Ma}) \\
\text { Cambrian }(504.5 \pm 1.8 \mathrm{Ma}) \\
\text { Ordovician } \\
\text { Ordovician }(486.7 \pm 8.8 \mathrm{Ma}) \\
\text { Ordovician }(466.2 \pm 3.6 \mathrm{Ma})\end{array}$ & $216 / 37$ & 4 & 0 & 18 & 71 & 7 \\
\hline Ballèvre et al. (2012) & $\begin{array}{l}\text { FL-31 } \\
\text { CG13a } \\
\text { CG5 } \\
\text { CG09 } \\
\text { F12a } \\
\end{array}$ & $\begin{array}{l}\text { Bréthomé } \\
\text { Chie-Loup } \\
\text { Mareuil / Lay } \\
\text { La Sauzaie } \\
\text { Sauzon } \\
\end{array}$ & & $\begin{array}{c}\text { Felsic } \\
\text { (meta)volcanics }\end{array}$ & $\begin{array}{c}\text { Ordovician }(472 \pm 4 \mathrm{Ma}) \\
\text { Ordovician }(486 \pm 4 \mathrm{Ma}) \\
\text { Ordovician }(478 \pm 2 \mathrm{Ma}) \\
\text { Ordovician }(491 \pm 12 \mathrm{Ma}) \\
\text { Ordovician }(494 \pm 4 \mathrm{Ma})\end{array}$ & $71 / 0$ & 1 & 0 & 6 & 93 & 0 \\
\hline Vernhet et al. (2012) & $\begin{array}{l}\text { Pertre } 1 \\
\text { Pertre } 4 \\
\text { Pertre } 6 \\
\end{array}$ & Pertre & 7 & MPG & $\begin{array}{c}\text { Lower Carboniferous }(345 \pm 3 \mathrm{Ma}) \\
\text { Lower Carboniferous }(348 \pm 19 \mathrm{Ma}) \\
\text { Lower Carboniferous }(340 \pm 2 \mathrm{Ma}) \\
\end{array}$ & $41 / 0$ & 0 & 0 & 2 & 0 & 93 \\
\hline $\begin{array}{l}\text { Ballouard et al. (2015) } \\
\text { This study }\end{array}$ & $\begin{array}{l}\text { GUE-3 } \\
\text { GUE-4 } \\
\text { GUE-5 }\end{array}$ & Guérande & 6 & MPG & $\begin{array}{l}\text { Upper Carboniferous }(309.4 \pm 1.9 \mathrm{Ma}) \\
\text { Upper Carboniferous }(309.7 \pm 1.3 \mathrm{Ma}) \\
\text { Upper Carboniferous (302.5 } \pm 1.6 \mathrm{Ma})\end{array}$ & $52 / 32$ & 4 & 8 & 50 & 13 & 25 \\
\hline $\begin{array}{l}\text { Ballouard et al. (2017b) } \\
\qquad \text { This study } \\
\text { Ballouard et al. (2017b) }\end{array}$ & $\begin{array}{l}\text { PONT-1 } \\
\text { PONT-10 } \\
\text { PONT-14 } \\
\text { PONT-15 } \\
\text { PONT-26 }\end{array}$ & Pontivy & 5 & MPG & $\begin{array}{c}\text { Upper Carboniferous }(316.7 \pm 2.5 \mathrm{Ma}) \\
\text { Upper Carboniferous } \\
\text { Upper Carboniferous }(310.3 \pm 4.7 \mathrm{Ma})\end{array}$ & $83 / 24$ & 8 & 1 & 39 & 20 & 31 \\
\hline Ballouard et al. (2017b) & PONT-20 & Langonnet & 4 & MPG & Upper Carboniferous $(304.7 \pm 2.7 \mathrm{Ma}$ ) & $28 / 18$ & 4 & 0 & 39 & 32 & 25 \\
\hline This study & QRT-08 & Questembert & 3 & MPG & Upper Carboniferous $(316.1 \pm 2.9 \mathrm{Ma})$ & $19 / 15$ & 5 & 0 & 21 & 47 & 26 \\
\hline $\begin{array}{l}\text { This study, Tartèse et al. } \\
\text { (2011a) } \\
\text { Tartèse et al. (2011a) }\end{array}$ & $\begin{array}{l}\text { LRT-10 } \\
\text { LRT-15 }\end{array}$ & Lizio & 2 & MPG & $\begin{array}{l}\text { Upper Carboniferous ( } 316.4 \pm 5.6 \mathrm{Ma}) \\
\text { Upper Carboniferous }(319 \pm 15 \mathrm{Ma})\end{array}$ & $29 / 18$ & 0 & 3 & 59 & 28 & 10 \\
\hline This study & HUEL-3 & Huelgoat & 1 & MPG & Upper Carboniferous $(314.0 \pm 2.8 \mathrm{Ma})$ & $18 / 0$ & 6 & 0 & 50 & 17 & 28 \\
\hline
\end{tabular}

Table 1: summary of zircon U-Pb data. Pop. = population. 